\title{
A systematic review and meta-analysis of Anakinra, Sarilumab, Siltuximab and Tocilizumab for Covid-19
}

\section{Authors:}

Dr Fasihul Khan. Respiratory Medicine, University of Nottingham, Clinical Sciences Building, Nottingham City Hospital, Hucknall Road, Nottingham, UK

Dr lain Stewart. Respiratory Medicine, University of Nottingham, Clinical Sciences Building, Nottingham City Hospital, Hucknall Road, Nottingham, UK

Dr Laura Fabbri. Respiratory Medicine, University of Nottingham, Clinical Sciences Building, Nottingham City Hospital, Hucknall Road, Nottingham, UK

Samuel Moss, Respiratory Medicine, University of Nottingham, Clinical Sciences Building, Nottingham City Hospital, Hucknall Road, Nottingham, UK

Professor Karen A. Robinson. John Hopkins University

Professor Alan Smyth. Division of Child Health, Obstetrics \& Gynaecology, University of Nottingham, Nottingham, UK

Professor Gisli Jenkins. Respiratory Medicine, University of Nottingham, Clinical Sciences Building, Nottingham City Hospital, Hucknall Road, Nottingham, UK

\section{Correspondence to:}

Dr Fasihul Khan fasihul.khan@nottingham.ac.uk

Total word count: 3494

Abstract word count: 250

PROSPERO registration number: CRD42020176375

Date of registration: $25^{\text {th }}$ March 2020 


\section{ABSTRACT}

\section{Background}

There is accumulating evidence for an overly activated immune response in severe Covid19, with several studies exploring the therapeutic role of immunomodulation. Through systematic review and meta-analysis, we assess the effectiveness of specific interleukin inhibitors for the treatment of Covid-19.

\section{Methods}

Electronic databases were searched on $7^{\text {th }}$ January 2021 to identify studies of immunomodulatory agents (anakinra, sarilumab, siltuximab and tocilizumab) for the treatment of Covid-19. The primary outcomes were severity on an ordinal scale measured at day 15 from intervention and days to hospital discharge. Key secondary endpoints included overall mortality.

\section{Results}

71 studies totalling 22,058 patients were included, six were randomised trials. Most explored outcomes in patients who received tocilizumab (59/71). In prospective studies, tocilizumab was associated with improved unadjusted survival $\left(\mathrm{RR} 0.8395 \% \mathrm{Cl} 0.72 ; 0.96 \mathrm{I}^{2}=\right.$ $0.0 \%$ ), but conclusive benefit was not demonstrated for other outcomes. In retrospective studies, tocilizumab was associated with less severe outcomes on an ordinal scale (Generalised odds ratio $1.3495 \% \mathrm{Cl} 1.10 ; 1.64, \mathrm{I}^{2}=98 \%$ ) and adjusted mortality risk (HR 0.52 
$\left.95 \% \mathrm{Cl} 0.41 ; 0.66, \mathrm{I}^{2}=76.6 \%\right)$. The mean difference in duration of hospitalisation was 0.36

days $\left(95 \% \mathrm{Cl}-0.07 ; 0.80, \mathrm{I}^{2}=93.8 \%\right)$. There was substantial heterogeneity in retrospective

studies, and estimates should be interpreted cautiously. Other immunomodulatory agents

showed similar effects to tocilizumab, but insufficient data precluded meta-analysis by

agent.

\section{Conclusion}

Tocilizumab was associated with a lower relative risk of mortality in prospective studies, but effects were inconclusive for other outcomes. Current evidence for the efficacy of anakinra, siltuximab or sarilumab in Covid-19 is insufficient, with further studies urgently needed for conclusive findings. 


\section{INTRODUCTION}

The novel severe acute respiratory syndrome coronavirus 2 (SARS-CoV-2) was first identified in Wuhan, China in December 2019(1). Since then, coronavirus disease 2019 (Covid-19) has been declared a global pandemic by the World Health Organisation (WHO) and continues to spread at an exponential rate with almost two million deaths reported worldwide $(2,3)$.

The clinical manifestations of Covid-19 tend to be heterogenous ranging from asymptomatic infection to acute respiratory disease syndrome (ARDS), multi-organ failure and death. Mechanisms underlying severe disease are incompletely understood, but accumulating evidence points towards a dysregulated and excessive host immune response referred to as cytokine storm syndrome (CSS)(4). During this state of immunological hyperactivation, increased circulating levels of pro-inflammatory cytokines including interleukin (IL)-1 and IL-

6 have been demonstrated, and are associated with adverse clinical outcomes (5-7). Suppression of pro-inflammatory cytokines in Covid-19 may therefore be a potential therapeutic strategy (8).

SARS-CoV-2 shares a number of genetic and clinical similarities with other zoonotic coronaviruses, including severe acute respiratory syndrome coronavirus (SARS) and Middle East respiratory syndrome $(\operatorname{MERS})(9,10)$. There are also reports of elevated proinflammatory cytokines in patients with SARS and MERS $(11,12)$, suggesting overlapping therapeutic targets in the management of SARS, MERS and Covid-19. 
Several clinical studies evaluating the role of immunomodulatory agents in Covid-19 have been published recently. Through systematic review and critical appraisal of the literature, we assess the effectiveness and safety of specific IL-1 (anakinra) and IL-6 (tocilizumab, siltuximab, sarilumab) inhibitors for the treatment of Covid-19, drawing on literature from previous similar coronavirus infections (SARS and MERS) where available. These agents already carry approval for the treatment of other rare non-infectious and autoimmune conditions, with an acceptable safety profile.

\section{METHODS}

The systematic review was conducted in accordance with a pre-specified protocol (PROSPERO registration number: CRD42020176375), and has been reported in accordance with PRISMA (Preferred Reporting Items for Systematic Reviews and Meta-Analyses) guidelines(13).

\section{Search strategy and study selection}

Electronic database searches were carried out in MEDLINE (1946 to latest) and EMBASE (1974 to latest), and ongoing clinical trial registries (clinicaltrials.gov and EU Clinical Trials Register), with the last search carried out on $7^{\text {th }}$ January 2021. Search terms were broad and included keywords and controlled vocabulary for patient and treatment-related terms (Figure S1 for MEDLINE search strategy). Unpublished and ongoing studies were identified by searching pre-print servers including medRxiv and bioRxiv. Searches were carried out independently by two reviewers in a standardised manner, followed by screening through 
titles and abstracts, before full text review. Disagreements were resolved by consensus, with unresolved conflicts decided by a third reviewer.

The review included all original studies excluding case reports, evaluating the use of at least one of anakinra, tocilizumab, sarilumab or siltuximab in patients aged over 18 with either suspected or confirmed Covid-19, SARS or MERS. Retrospective studies without a comparator arm were excluded due to their associated heterogeneity and inherent risk of bias. Language or year of publication restrictions were not applied. No minimal study sample size was specified for inclusion.

The planned primary outcomes were selected based on their clinical usefulness and included time to hospital discharge (days) and severity on an adapted four-point ordinal scale at day 15 following intervention, with the following ratings: i) death; ii) requirement for invasive mechanical ventilation (IMV) or Extra Corporal Membrane Oxygenation (ECMO); iii) hospitalised but no requirement for IMV/ECMO; iv) not hospitalised. Secondary outcomes included time to clinical improvement (days), duration of mechanical ventilation (days), overall mortality, mortality at 28 days and treatment related adverse events. For all outcomes studied, baseline was defined as the day of intervention.

\section{Data extraction and risk of bias assessment}

Data were extracted from article text and figures using a data-extraction proforma and verified by a second reviewer. Information sought included study design, sample size, participant demographics, clinical investigation findings, intervention characteristics (name 
of agent, dose, route), treatment related adverse events, requirement and duration of invasive and non-invasive ventilation, use and dosage of oxygen, duration of hospital stay, survival outcome measures and follow up duration. Where ordinal outcomes were reported at multiple timepoints, those closest to day 15 post intervention were chosen for extraction. For ongoing trial protocols, the registration number, sample size, and expected date of completion were recorded.

Risk of bias assessment was carried out independently in duplicate. Due to the heterogeneity of study designs, various quality assessment tools available through the National Institute of Health were applied(14). The tools assess risk of bias through criterion specific to each study design, before providing an overall quality rating of good, fair or poor. Randomised studies were assessed using the Cochrane risk-of-bias tool for randomised trials (RoB2)(15). As per the review protocol, all studies were included irrespective of their risk of bias rating. Using the GRADE approach, we rated the overall quality of evidence for each outcome as high, moderate, low or very low(16).

\section{Statistical analysis}

All identified studies were included in the narrative summary with summary tables for characteristics. For the primary outcomes, numbers of individuals meeting each outcome on the adapted ordinal scale were pooled using rank-based Wilcoxon Mann Whitney tests with ties split evenly between positive and negative outcomes, providing a generalised odds ratio (GenOR) with 95\% confidence intervals $(\mathrm{Cl})$. The GenOR provides a measure of the 
likelihood that the intervention leads to a better rather than worse outcome when compared to a randomly chosen control (17). Mean hospital duration and standard deviation (SD) were extracted or were estimated from median and range/interquartile range (IQR) using the Box-Cox method (18). Mean difference in hospital stay was calculated where a control arm was reported. Where available, adjusted hazard ratios (HR) and unadjusted mortality data were extracted for quantitative synthesis. Where data were not reported in a tabular format, values were extracted from plotted data using a digital plot analyser(19).

Where sufficient studies were identified for a specific immunomodulator, findings were assessed using random effects meta-analysis and presented as forest plots. Meta-analyses were grouped by retrospective and prospective design and presented on the same plots with no overall estimate. The $\mathrm{I}^{2}$ statistic was used to evaluate statistical heterogeneity. Although sample sizes were limited, we used pseudo- $\mathrm{R}^{2}$ from meta-regression to explore variability in heterogeneity owing to study design (single-centre or multicentre), non-peer reviewed manuscripts, concomitant use of steroids, route of drug administration (intravenous or subcutaneous), and day outcome measured. Publication bias was assessed using funnel plot analysis and Egger's test. Prospective studies without a control arm were excluded from meta-analysis and presented either in the narrative summary or in tables. All analyses were performed using Stata v.16 (StataCorp, College Station, TX, USA).

\section{RESULTS}


Search of the electronic databases (MEDLINE and EMBASE) on $7^{\text {th }}$ January 2021 yielded a total of 2585 studies, with a further 576 studies identified through preprint servers. Following removal of duplicates, screening and full text review, 71 articles published worldwide were shortlisted for inclusion (anakinra, $n=6$; tocilizumab, $n=58$; anakinra and tocilizumab, $n=1$; sarilumab and tocilizumab, $n=1$; sarilumab, $n=4$; siltuximab, $n=1$ ) (Figure 1). Sixty-two studies were published in peer-reviewed journals, with the remaining nine identified through preprint servers. All studies were performed in patients with Covid-19, with no suitable studies identified for SARS or MERS. Twenty-nine studies were prospective in design, with seventeen studies including a control group for comparison, of which six were randomised studies. The remaining 42 studies were retrospective studies with control arms. Included studies provided a total of 22,058 patients, of which 7328 (33\%) received one of the therapies under review alongside standard of care (SOC), and 14730 (67\%) received SOC alone. Individual study characteristics for the published studies are presented in Tables 1 and 2 (and Tables S1-S2)

Risk of bias assessment of the retrieved studies identified multiple limitations and highlighted a number of biases (Figure 2 and Table S3). The majority of included studies defined the study population specifically with clear inclusion/exclusion criteria. Where applicable, control participants were selected from the same population. However, many studies provided insufficient detail of the interventions and outcomes being studied or reporting was inconsistent, with key design, and outcome details omitted. Statistical analysis was variably reported, with few studies providing a sample size justification. In nearly all studies, patients were on concomitant therapies, limiting the ability to discern whether a specific intervention was related to the outcome. Following a formal risk of bias 
assessment, $23(32 \%)$ studies were rated as good, 37 (52\%) fair and 11 (15\%) poor. Publication bias, assessed by observation of funnel plots and Egger's test, was not present for any of the outcomes assessed (Figure S2).

\section{Tocilizumab}

Twelve prospective studies with a control arm, eight prospective studies without a control arm, and 40 retrospective studies examining the clinical impact of tocilizumab in Covid-19 were identified. Amongst the prospective studies there were six randomised clinical trials (RCTs). In total, the studies reported outcomes from 20,972 patients, of whom 6563 (31\%) were given tocilizumab. Criteria for eligible participants varied across the studies, with many specifying respiratory failure with laboratory evidence of hyperinflammation as a prerequisite. The dose of tocilizumab administration was not entirely consistent with intravenous $8 \mathrm{mg} / \mathrm{kg}$ or $400 \mathrm{mg}$ the most commonly studied route and dose.

Ordinal scale

A total of 12 studies provided outcomes on an adapted 4-point scale for 1782 patients including cases and controls (Table S4). The median time for reporting outcomes after treatment was 14 days (IQR 14-28). The recently available REMAP-CAP adaptive RCT interim analysis reported a signal that tocilizumab was associated with clinical improvement at day 14 (aOR $1.8395 \% \mathrm{Cl} 1.40 ; 2.41)(20)$, whilst in a separate $\mathrm{RCT}$, outcomes on an ordinal severity scale did not differ between the treatment groups (HR $1.0695 \% \mathrm{Cl} 0.80 ; 1.41)(21)$. Distinctions in statistical methodology and clinical endpoints precluded inclusion of these 
RCT in the specified meta-analysis. Tocilizumab was not associated with better outcomes on the ordinal scale in meta-analysis of the remaining prospective studies, including three RCTs (GenOR $1.0995 \% \mathrm{Cl} 0.99 ; 1.19, \mathrm{I}^{2}=84.3 \%$ ) (Figure 3). Variability in reported concomitant steroid administration had a significant contribution upon the substantial heterogeneity observed (Table S5). Tocilizumab was associated with better outcomes in meta-analysis of retrospective studies, indicating a $34 \%$ greater chance of less-severe outcomes on the adapted ordinal scale when compared to control (GenOR $1.3495 \% \mathrm{Cl} 1.10 ; 1.64, \mathrm{I}^{2}=98 \%$ ). However, these results should be interpreted with caution as there was severe heterogeneity which could not be explained by variability in the factors assessed.

Duration of hospitalisation

Two RCTs and nine retrospective studies reported the duration of hospitalisation for a total of 1553 survivors who received tocilizumab (Figure 4). Individual RCTs comparing the duration of hospitalisation with controls identified associations of tocilizumab with a reduced hospital stay $(-0.34$ days $95 \% \mathrm{Cl}-0.55 ;-0.12)(22)$ and earlier hospital discharge (aHR $1.4195 \% \mathrm{Cl} 1.18 ; 1.70)(20)$. Retrospective studies reporting the duration of hospitalisation were combined to give an overall summary estimate $\left(20.98\right.$ days $95 \% \mathrm{Cl} 16.19 ; 25.78, \mathrm{I}^{2}=$ 97.1\%), which was greater than the duration reported by RCTs $(14.55$ days $95 \% \mathrm{Cl}$ $\left.0.37 ; 29.67, \mathrm{I}^{2}=99.9 \%\right)$. Compared with 943 patients in retrospective studies who received SOC only, tocilizumab was not associated with a difference in the mean duration of hospital stay $\left(0.36\right.$ days $\left.95 \% \mathrm{Cl}-0.07 ; 0.80, \mathrm{I}^{2}=93.8 \%\right)$, with variability in route of administration (intravenous or subcutaneous) associated with the severe heterogeneity in this estimate $\left(\mathrm{R}^{2}\right.$ $=81.64 \%, \mathrm{p}<0.001)$. 
Overall mortality

Twenty-two studies totalling 13,702 patients reported adjusted hazard ratios for overall mortality, at a follow up time censored at a median of 28 days (IQR 14-30). Amongst the studies, two were RCTs and neither reported a difference between tocilizumab and control for mortality $(21,23)$. When prospective tocilizumab studies were pooled there was an emerging survival benefit, but the estimate was inconclusive (HR $0.7095 \% \mathrm{Cl} 0.44 ; 1.10, \mathrm{I}^{2}=$ $0 \%)$ (Figure 5). In the remaining retrospective studies, tocilizumab was associated with a $48 \%$ lower risk of adjusted mortality with substantial heterogeneity ( $\mathrm{HR} \quad 0.5295 \% \mathrm{Cl}$ $\left.0.41 ; 0.66, I^{2}=76.6 \%\right)$. Meta-regression identified day outcome measured as a significant source of heterogeneity $\left(R^{2}=99.99, p=0.08\right)$.

Risk ratios (RR) were calculated from 42 studies, including six RCTs, reporting unadjusted mortality data for 15,085 patients at a median follow up of 24 days (IQR 14-28) (Figure 6). Tocilizumab was associated with a $17 \%$ lower unadjusted risk of mortality compared with the control arm in prospective studies ( $\mathrm{RR} 0.8395 \% \mathrm{Cl} 0.72 ; 0.96, \mathrm{I}^{2}=0.0 \%$ ), which did not reach significance in $\mathrm{RCTs}$ alone (RR $0.8595 \% \mathrm{Cl} 0.71 ; 1.01 \mathrm{I}^{2}=0.0 \%$ ) (Figure S3). Within retrospective studies, tocilizumab was associated with a $24 \%$ lower risk of mortality (RR 0.76 $\left.95 \% \mathrm{Cl} 0.64 ; 0.92, \mathrm{I}^{2}=80.3 \%\right)$, although there was substantial heterogeneity which could not be explained by variability in the factors assessed. The combined case fatality (CFR) across all studies included in the meta-analysis was $21.2 \%(1118 / 5284)$ in the intervention arm and 31.1\% (3049/9801) in the control arm. The CFR from single arm prospective studies unable to be included in meta-analysis was $17.8 \%(113 / 634)$. 


\section{Other immunomodulators}

Studies exploring outcomes in patients who received anakinra, sarilumab or siltuximab were not quantitively synthesised for all outcomes, owing to differences in outcomes reported, study design and limited study numbers. Similar to studies in tocilizumab, participant criteria were inconsistent but typically included patients with respiratory failure and signs of hyperinflammation. Doses of therapeutic agents ranged from 200-600mg daily for anakinra, and 200-400mg daily for sarilumab. In all studies, patients received concomitant medications including but not limited to antivirals, hydroxychloroquine and corticosteroids. Meta-analysis inclusive of all immunomodulatory agents without sub analysis are presented in Figures S4-S7.

Anakinra

Four prospective and three retrospective studies exploring outcomes in 346 patients who received anakinra and 3339 controls were retrieved. Three studies reported ordinal outcome data for both anakinra and control participants, although the outcome day varied. Anakinra was associated with improved clinical outcomes in two retrospective studies of 22 and 45 patients, respectively $(24,25)$. A similar association with improved clinical outcomes was reported on day 14 in a prospective study of 69 patients (GenOR $1.7795 \% \mathrm{Cl}$ 1.52;2.06)(26). Two studies reported adjusted HR for mortality with supportive results. A significant association was not observed in a retrospective study of 57 treated patients (aHR 
$0.7995 \% \mathrm{Cl} 0.44 ; 1.42)(27)$, whilst an association was observed in a prospective study of 130 patients (aHR $0.4995 \% \mathrm{Cl} 0.26 ; 0.91)(28)$. A significant unadjusted association was also observed in a further study of 52 patients treated with anakinra ( $\mathrm{HR} 0.30 ; 95 \% \mathrm{Cl} 0.12-$ $0.71)(29)$. Risk ratios were calculated from four studies totalling 424 participants. In a retrospective study of 29 treated patients, anakinra improved survival (RR $0.2495 \% \mathrm{Cl}$ $0.07 ; 0.79$ ); associations were inconclusive when prospective studies were pooled (RR 0.70 $95 \% \mathrm{Cl} 0.31 ; 1.58, \mathrm{I}^{2}=32.8 \%$ ) (Figure S8). No studies compared the duration of hospitalisation between recipients and non-recipients of anakinra.

Sarilumab

Five prospective studies exploring outcomes in 389 participants who received sarilumab were included. In the only RCT identified, sarilumab was associated with increased survival (aOR $2.0195 \% \mathrm{Cl} 1.18 ; 4.71$ ), reduced duration of hospitalisation (aHR $1.6095 \% \mathrm{Cl} 1.17 ; 2.40$ ) and improved ordinal outcomes at day 14 (aOR $1.8695 \% \mathrm{Cl} 1.22 ; 2.91)(20)$. In a further nonrandomised study of 28 participants (30), sarilumab was not significantly associated with mortality (aHR $0.3695 \% \mathrm{Cl} 0.08 ; 1.68$ ) and comparable effects were observed amongst treated and non-treated patients with respect to ordinal outcomes (GenOR $1.0795 \% \mathrm{Cl}$ $0.90 ; 1.27)$ and duration of hospitalisation (mean difference $0.0295 \% \mathrm{Cl}-0.51 ; 0.54$ ). The combined CFR across the five included studies was $11 \%$ (43/389) for sarilumab, whilst in the only study reporting control mortality data the CFR was $35.8 \%(142 / 397)$.

Siltuximab 
A single prospective cohort study of siltuximab studying outcomes in 60 patients was identified(31). Neither ordinal outcome data nor duration of hospitalisation were reported, but the adjusted risk of mortality was reported to be significantly lower in patients who received siltuximab (aHR $0.4695 \% \mathrm{Cl} 0.22 ; 0.97)$.

\section{Treatment related adverse events}

Treatment related adverse events were reported in most studies (70\%) and typically included secondary bacterial infections and derangement of liver enzymes (Table 2). In studies with a comparator arm exploring outcomes from patients who received anakinra or sarilumab, the frequency of treatment related adverse events was similar in both treatment and comparator groups. Findings from studies reporting outcomes following tocilizumab administration were inconsistent. In five studies, tocilizumab recipients had an increased prevalence of secondary infections compared with controls. However, in twelve studies, tocilizumab was associated with a lower or similar rate of secondary infections compared with controls.

\section{Clinical trials}

Sixty-two planned or in-process clinical trials (tocilizumab, 44; siltuximab, 4; sarilumab, 9; anakinra, 13) were identified through clinical registry searches, with some clinical trials exploring more than one immunomodulatory agent. Currently registered clinical trials and their estimated dates of completion are provided in Figure S9. 


\section{DISCUSSION}

In this systematic review and meta-analysis, we summarise and evaluate the association between immunomodulatory agents and multiple outcomes in Covid-19. Although there was severe heterogeneity across tocilizumab studies exploring outcomes on an adapted four-point ordinal scale, a beneficial effect of tocilizumab was suggested in retrospective studies compared with controls. Prospective studies followed a similar direction of association, though confidence intervals were not conclusive. The certainty of the findings related to the adapted ordinal severity scale are assessed as moderate using GRADE (Table S6). The mean duration of hospitalisation was not altered by intervention, with low certainty of findings. Tocilizumab was associated with a survival benefit that was consistent across retrospective and prospective studies, with pooled analysis of unadjusted risk ratios demonstrating a $17 \%$ reduced risk of mortality in prospective studies. We assess the certainty of our findings related to overall mortality as high.

Due to heterogeneity in study designs and reported outcomes, studies in patients receiving immunomodulatory agents other than tocilizumab were not quantitatively synthesised for all outcomes. In the only study reporting adjusted HRs, anakinra was associated with reduced mortality. However, pooled analysis of unadjusted ratios in non-randomised studies did not demonstrate a mortality benefit. A single sarilumab RCT demonstrated that intervention was associated with improved outcomes and reduced hospital stay. No randomised studies were identified for siltuximab. For all agents included in this review, the 
frequency of adverse events was similar in the treatment and control arms. Sixty-one registered clinical trials exploring immunomodulatory agents in Covid-19 were identified, of which some have completed and been published.

In this review we highlight multiple limitations and considerable sources of inter-study heterogeneity. The majority of included studies were non-randomised cohorts of relatively modest size. Although most studies necessitated respiratory failure requiring at least basic respiratory support, participant criteria were not entirely consistent across the studies. The dosage and delivery of therapy varied across many of the non-randomised studies, and in nearly all studies patients were on concomitant medications such as antivirals, hydroxychloroquine and steroids with administration at the discretion of the treating physician, precluding causal associations of specific interleukin inhibitors with outcomes. Study outcomes were heterogeneous and a combination of clinical, laboratory and radiological outcomes were reported, rather than a single consistent endpoint. Furthermore, there was inconsistency in the duration of follow up and timing of reported outcomes. Individual patient data (IPD) may have mitigated some of these limitations, but in a rapidly progressing area, seeking IPD was deemed to be unrealistic due to the associated delays. We also observed significant statistical heterogeneity as measured by $\mathrm{I}^{2}$, and therefore the findings of our meta-analysis should be interpreted with caution. We were unable to explain all the residual heterogeneity using the factors we assessed, although concomitant steroid use, route of drug administration and day outcome measured appeared to contribute within specific outcomes. 
To maximise value and timeliness of our review of four specific immunomodulators, two primary endpoints and a number of secondary endpoints, we included both retrospective and preprint studies. Risk of bias was minimised by restricting analysis of non-prospective studies to those with a control group, and caution is used to present summaries separately. We did not detect any significant publication bias in the reporting of effects. Where there was insufficient data for meta-analysis, summary outcomes were presented with qualitative synthesis to ensure the review was comprehensive. The data presented here represent findings from different countries, offering diversity in ethnic background. We were unable to identify suitable studies in SARS or MERS to comment on the generalisability of immunomodulators in other coronavirus outbreaks.

In conclusion, this systematic review provides the most up-to-date and complete evidence for a range of specific immunomodulatory therapies in the management of Covid-19. We have established that evidence for the efficacy of anakinra, siltuximab or sarilumab in Covid19 is currently insufficient and adequately powered high-quality randomised clinical studies are urgently needed. We demonstrate through quantitative synthesis of retrospective studies that tocilizumab intervention was frequently associated with improved outcomes and reduced mortality. However, data were highly heterogeneous and must be interpreted with caution. Prospective studies demonstrated a $17 \%$ lower unadjusted risk of mortality with tocilizumab, with minimal heterogeneity and similar adjusted estimates. Further research should focus on identifying participant and disease characteristics where immunomodulatory therapy is likely to be of maximal effectiveness, whilst also exploring the relationship with baseline inflammatory biomarkers such as interleukin- 6 and $C$ reactive 
medRxiv preprint doi: https://doi.org/10.1101/2020.04.23.20076612; this version posted January 18, 2021. The copyright holder for this preprint (which was not certified by peer review) is the author/funder, who has granted medRxiv a license to display the preprint in perpetuity. It is made available under a CC-BY 4.0 International license.

protein. In summary, we demonstrate tocilizumab is associated with lower mortality in Covid-19, and other immunomodulatory therapies are worth exploring further.

Funding: FK/LF/IS/AS are supported by the Nottingham National Institute for Health Research (NIHR) Biomedical Research Centre. RGJ is supported by an NIHR Research Professorship (RP-2017-08-ST2-014). 


\section{References}

1. Huang C, Wang Y, Li X, Ren L, Zhao J, Hu Y, et al. Clinical features of patients infected with 2019 novel coronavirus in Wuhan, China. Lancet (London, England). 2020;395(10223):497-506.

2. WHO Director-General's opening remarks at the media briefing on COVID-19 - 11 March 20202020 [Available from: https://www.who.int/dg/speeches/detail/who-directorgeneral-s-opening-remarks-at-the-media-briefing-on-covid-19---11-march-2020.

3. Johns Hopkins University of Medicine COVID-19 dashboard by the Center for Systems Science and Engineering (CSSE) at Johns Hopkins University (JHU). https://coronavirusjhuedu/maphtml.

4. Mehta P, McAuley DF, Brown M, Sanchez E, Tattersall RS, Manson JJ. COVID-19: consider cytokine storm syndromes and immunosuppression. The Lancet. 2020;395(10229):1033-4.

5. Qin C, Zhou L, Hu Z, Zhang S, Yang S, Tao Y, et al. Dysregulation of immune response in patients with COVID-19 in Wuhan, China. Clin Infect Dis. 2020.

6. Coomes EA, Haghbayan H. Interleukin-6 in COVID-19: A Systematic Review and Meta-Analysis. medRxiv. 2020:2020.03.30.20048058.

7. Lucas C, Wong P, Klein J, Castro TBR, Silva J, Sundaram M, et al. Longitudinal analyses reveal immunological misfiring in severe COVID-19. Nature. 2020;584(7821):463-9.

8. Conti P, Ronconi G, Caraffa A, Gallenga CE, Ross R, Frydas I, et al. Induction of proinflammatory cytokines (IL-1 and IL-6) and lung inflammation by Coronavirus-19 (COVI-19 or SARS-CoV-2): anti-inflammatory strategies. J Biol Regul Homeost Agents. 2020;34(2).

9. Cheng ZJ, Shan J. 2019 Novel coronavirus: where we are and what we know. Infection. 2020;48(2):155-63.

10. Hui DS, E IA, Madani TA, Ntoumi F, Kock R, Dar O, et al. The continuing 2019-nCoV epidemic threat of novel coronaviruses to global health - The latest 2019 novel coronavirus outbreak in Wuhan, China. Int J Infect Dis. 2020;91:264-6.

11. Wong CK, Lam CW, Wu AK, Ip WK, Lee NL, Chan IH, et al. Plasma inflammatory cytokines and chemokines in severe acute respiratory syndrome. Clin Exp Immunol. 2004;136(1):95-103.

12. Mahallawi WH, Khabour OF, Zhang Q, Makhdoum HM, Suliman BA. MERS-CoV infection in humans is associated with a pro-inflammatory Th1 and Th17 cytokine profile. Cytokine. 2018;104:8-13.

13. Liberati A, Altman DG, Tetzlaff J, Mulrow C, Gøtzsche PC, loannidis JP, et al. The PRISMA statement for reporting systematic reviews and meta-analyses of studies that evaluate healthcare interventions: explanation and elaboration. Bmj. 2009;339:b2700.

14. National Heart L, National Institute of Health. https://www.nhlbi.nih.gov/healthtopics/study-quality-assessment-tools [

15. Sterne JAC, Savović J, Page MJ, Elbers RG, Blencowe NS, Boutron I, et al. RoB 2: a revised tool for assessing risk of bias in randomised trials. Bmj. 2019;366:14898. 
16. Granholm A, Alhazzani W, Møller MH. Use of the GRADE approach in systematic reviews and guidelines. Br J Anaesth. 2019;123(5):554-9.

17. Churilov L, Arnup S, Johns H, Leung T, Roberts S, Campbell BCV, et al. An Improved Method for Simple, Assumption-Free Ordinal Analysis of the Modified Rankin Scale Using Generalized Odds Ratios. International Journal of Stroke. 2014;9(8):999-1005.

18. McGrath S, Zhao X, Steele R, Thombs BD, Benedetti A. Estimating the sample mean and standard deviation from commonly reported quantiles in meta-analysis. Statistical Methods in Medical Research. 2020;29(9):2520-37.

19. WebPlotDigitizer. https://apps.automeris.io/wpd/ [

20. Gordon AC. Interleukin-6 Receptor Antagonists in Critically III Patients with Covid-19 - Preliminary report. medRxiv. 2021:2021.01.07.21249390.

21. Stone JH, Frigault MJ, Serling-Boyd NJ, Fernandes AD, Harvey L, Foulkes AS, et al. Efficacy of Tocilizumab in Patients Hospitalized with Covid-19. New England Journal of Medicine. 2020.

22. Salama C, Han J, Yau L, Reiss WG, Kramer B, Neidhart JD, et al. Tocilizumab in Patients Hospitalized with Covid-19 Pneumonia. New England Journal of Medicine. 2020. 23. Hermine O, Mariette X, Tharaux P-L, Resche-Rigon M, Porcher R, Ravaud P, et al. Effect of Tocilizumab vs Usual Care in Adults Hospitalized With COVID-19 and Moderate or Severe Pneumonia: A Randomized Clinical Trial. JAMA Internal Medicine. 2020.

24. Cauchois R, Koubi M, Delarbre D, Manet C, Carvelli J, Blasco VB, et al. Early IL-1 receptor blockade in severe inflammatory respiratory failure complicating COVID-19. Proceedings of the National Academy of Sciences. 2020;117(32):18951-3.

25. Cavalli G, De Luca G, Campochiaro C, Della-Torre E, Ripa M, Canetti D, et al. Interleukin-1 blockade with high-dose anakinra in patients with COVID-19, acute respiratory distress syndrome, and hyperinflammation: a retrospective cohort study. The Lancet Rheumatology. 2020;2(6):e325-e31.

26. Balkhair A, Al-Zakwani I, Al Busaidi M, Al-Khirbash A, Al Mubaihsi S, BaTaher $\mathrm{H}$, et al. Anakinra in hospitalized patients with severe COVID-19 pneumonia requiring oxygen therapy: results of a prospective, open-label, interventional study. International Journal of Infectious Diseases. 2020;17:17.

27. Narain S, Stefanov DG, Chau AS, Weber AG, Marder G, Kaplan B, et al. Comparative Survival Analysis of Immunomodulatory Therapy for Coronavirus Disease 2019 Cytokine Storm. Chest. 2020;17:17.

28. Kyriazopoulou E, Panagopoulos P, Metallidis S, Dalekos GN, Poulakou G, Gatselis N, et al. Anakinra To Prevent Respiratory Failure In COVID-19. medRxiv.

2020:2020.10.28.20217455.

29. Huet T, Beaussier H, Voisin O, Jouveshomme S, Dauriat G, Lazareth I, et al. Anakinra for severe forms of COVID-19: a cohort study. The Lancet Rheumatology. 2020;2(7):e393e400.

30. Della-Torre E, Campochiaro C, Cavalli G, De Luca G, Napolitano A, La Marca S, et al. Interleukin-6 blockade with sarilumab in severe COVID-19 pneumonia with systemic hyperinflammation: An open-label cohort study. Annals of the rheumatic diseases. 2020;(no pagination).

31. Gritti G, Raimondi F, Ripamonti D, Riva I, Landi F, Alborghetti L, et al. IL-6 signalling pathway inactivation with siltuximab in patients with COVID-19 respiratory failure: an observational cohort study. medRxiv. 2020:2020.04.01.20048561. 
32. Roumier M, Paule R, Vallée A, Rohmer J, Ballester M, Brun A-L, et al. Tocilizumab for Severe Worsening COVID-19 Pneumonia: a Propensity Score Analysis. Journal of clinical immunology. 2020:1-12.

33. Kimmig LM, Wu D, Gold M, Pettit NN, Pitrak D, Mueller J, et al. IL-6 Inhibition in Critically III COVID-19 Patients Is Associated With Increased Secondary Infections. Frontiers in Medicine. 2020;7(689).

34. Klopfenstein T, Zayet S, Lohse A, Selles P, Zahra H, Kadiane-Oussou NJ, et al. Impact of Tocilizumab on mortality and/or invasive mechanical ventilation requirement in a cohort of 206 COVID-19 patients. International journal of infectious diseases : IJID : official publication of the International Society for Infectious Diseases. 2020;12.

35. Kooistra EJ, Waalders NJB, Grondman I, Janssen NAF, de Nooijer AH, Netea MG, et al. Anakinra treatment in critically ill COVID-19 patients: a prospective cohort study. Critical Care (London, England). 2020;24(1):688.

36. Salvarani C, Dolci G, Massari M, Merlo DF, Cavuto S, Savoldi L, et al. Effect of Tocilizumab vs Standard Care on Clinical Worsening in Patients Hospitalized With COVID-19 Pneumonia: A Randomized Clinical Trial. JAMA Internal Medicine. 2020.

37. Lewis TC, Adhikari S, Tatapudi V, Holub M, Kunichoff D, Troxel AB, et al. A Propensity-Matched Cohort Study of Tocilizumab in Patients With Coronavirus Disease 2019. Critical Care Explorations. 2020;2(11):e0283.

38. Sanchez-Montalva A, Selares-Nadal J, Espinosa-Pereiro J, Fernandez-Hidalgo N, Perez-Hoyos S, Salvador F, et al. Early outcomes of tocilizumab in adults hospitalized with severe COVID19. An initial report from the Vall dHebron COVID19 prospective cohort study. medRxiv. 2020:2020.05.07.20094599.

39. Martínez-Sanz J, Muriel A, Ron R, Herrera S, Pérez-Molina JA, Moreno S, et al. Effects of tocilizumab on mortality in hospitalized patients with COVID-19: a multicentre cohort study. Clinical Microbiology and Infection.

40. Sciascia S, Apra F, Baffa A, Baldovino S, Boaro D, Boero R, et al. Pilot prospective open, single-arm multicentre study on off-label use of tocilizumab in patients with severe COVID-19. Clinical and experimental rheumatology. 2020;38(3):529-32.

41. Nasa P, Singh A, Upadhyay S, Bagadia S, Polumuru S, Shrivastava PK, et al. Tocilizumab Use in COVID-19 Cytokine-release Syndrome: Retrospective Study of Two Centers. Indian Journal of Critical Care Medicine. 2020;24(9):771-6.

42. Strohbehn GW, Heiss BL, Rouhani SJ, Trujillo JA, Yu J, Kacew AJ, et al. COVIDOSE: A Phase II Clinical Trial of Low-Dose Tocilizumab in the Treatment of Noncritical COVID-19 Pneumonia. Clinical Pharmacology \& Therapeutics.n/a(n/a).

43. Patel K, Gooley TA, Bailey N, Bailey M, Hegerova L, Batchelder A, et al. Use of the IL6R Antagonist Tocilizumab in Hospitalized COVID-19 Patients. Journal of Internal Medicine.n/a(n/a).

44. Benucci M, Giannasi G, Cecchini P, Gobbi FL, Damiani A, Grossi V, et al. COVID-19 pneumonia treated with Sarilumab: A clinical series of eight patients. Journal of Medical Virology. 2020.

45. Toniati P, Piva S, Cattalini M, Garrafa E, Regola F, Castelli F, et al. Tocilizumab for the treatment of severe COVID-19 pneumonia with hyperinflammatory syndrome and acute respiratory failure: A single center study of 100 patients in Brescia, Italy. Autoimmunity Reviews. 2020;19(7). 
46. Petrak RM, Van Hise NW, Skorodin NC, Fliegelman RM, Chundi V, Didwania V, et al. Early Tocilizumab Dosing is Associated with Improved Survival In Critically III Patients Infected With Sars-CoV-2. medRxiv. 2020:2020.10.27.20211433.

47. Biran N, Ip A, Ahn J, Go RC, Wang S, Mathura S, et al. Tocilizumab among patients with COVID-19 in the intensive care unit: a multicentre observational study. The Lancet Rheumatology. 2020.

48. Pettit NN, Nguyen CT, Mutlu GM, Wu D, Kimmig L, Pitrak D, et al. Late onset infectious complications and safety of tocilizumab in the management of COVID-19. Journal of Medical Virology. 2020.

49. Canziani LM, Trovati S, Brunetta E, Testa A, De Santis M, Bombardieri E, et al. Interleukin-6 receptor blocking with intravenous tocilizumab in COVID-19 severe acute respiratory distress syndrome: A retrospective case-control survival analysis of 128 patients. Journal of Autoimmunity. 2020;(no pagination).

50. Potere N, Di Nisio M, Rizzo G, La Vella M, Polilli E, Agostinone A, et al. Low-Dose Subcutaneous Tocilizumab to Prevent Disease Progression in Patients with Moderate COVID-19 Pneumonia and Hyperinflammation. International journal of infectious diseases: IJID : official publication of the International Society for Infectious Diseases. 2020;05.

51. Gremese E, Cingolani A, Bosello SL, Alivernini S, Tolusso B, Perniola S, et al. Sarilumab use in severe SARS-CoV-2 pneumonia. EClinicalMedicine.

52. Capra R, De Rossi N, Mattioli F, Romanelli G, Scarpazza C, Sormani MP, et al. Impact of low dose tocilizumab on mortality rate in patients with COVID-19 related pneumonia. European journal of internal medicine. 2020;76:31-5.

53. Ramaswamy M, Mannam P, Comer R, Sinclair E, McQuaid DB, Schmidt ML. Off-Label Real World Experience Using Tocilizumab for Patients Hospitalized with COVID-19 Disease in a Regional Community Health System: A Case-Control Study. medRxiv.

2020:2020.05.14.20099234.

54. Sinha P, Mostaghim A, Bielick CG, McLaughlin A, Hamer DH, Wetzler LM, et al. Early administration of interleukin-6 inhibitors for patients with severe COVID-19 disease is associated with decreased intubation, reduced mortality, and increased discharge. International Journal of Infectious Diseases. 2020;99:28-33.

55. Chilimuri S, Sun H, Alemam A, Kang KS, Lao P, Mantri N, et al. Tocilizumab use in patients with moderate to severe COVID-19: A retrospective cohort study. Journal of Clinical Pharmacy \& Therapeutics. 2020;24:24.

56. Rodriguez-Bano J, Pachon J, Carratala J, Ryan P, Jarrin I, Yllescas M, et al. Treatment with tocilizumab or corticosteroids for COVID-19 patients with hyperinflammatory state: a multicentre cohort study (SAM-COVID-19). Clinical Microbiology \& Infection. 2020;27:27. 57. De Rossi N, Scarpazza C, Filippini C, Cordioli C, Rasia S, Mancinelli CR, et al. Early use of low dose tocilizumab in patients with COVID-19: A retrospective cohort study with a complete follow-up. EClinicalMedicine. 2020;25:100459.

58. Rojas-Marte G, Khalid M, Mukhtar O, Hashmi AT, Waheed MA, Ehrlich S, et al. Outcomes in patients with severe COVID-19 disease treated with tocilizumab: a casecontrolled study. QJM : monthly journal of the Association of Physicians. 2020;113(8):54650.

59. Albertini L, Soletchnik M, Razurel A, Cohen J, Bidegain F, Fauvelle F, et al. Observational study on off-label use of tocilizumab in patients with severe COVID-19. European Journal of Hospital Pharmacy Science \& Practice. 2020;10:10. 
60. Eimer J, Vesterbacka J, Svensson AK, Stojanovic B, Wagrell C, Sonnerborg A, et al. Tocilizumab shortens time on mechanical ventilation and length of hospital stay in patients with severe COVID-19: a retrospective cohort study. Journal of Internal Medicine. 2020.

61. Roomi S, Ullah W, Ahmed F, Farooq S, Sadiq U, Chohan A, et al. Efficacy of Hydroxychloroquine and Tocilizumab in Patients With COVID-19: Single-Center Retrospective Chart Review. Journal of medical Internet research. 2020;22(9):e21758.

62. Antony SJ, Davis MA, Davis MG, Almaghlouth NK, Guevara R, Omar F, et al. Early use of tocilizumab in the prevention of adult respiratory failure in SARS-CoV-2 infections and the utilization of interleukin- 6 levels in the management. Journal of Medical Virology. 2020;09:09.

63. Fisher MJ, Raymundo LAM, Monteforte M, Taub EM, Go R. Tocilizumab in the Treatment of Critical COVID-19 Pneumonia: A Retrospective Cohort Study of Mechanically Ventilated Patients. International Journal of Infectious Diseases. 2020;14:14.

64. Rosas J, Liano FP, Canto ML, Barea JMC, Beser AR, Rabasa JTA, et al. Experience With the Use of Baricitinib and Tocilizumab Monotherapy or Combined, in Patients With Interstitial Pneumonia Secondary to Coronavirus COVID19: A Real-World Study. Reumatologia Clinica. 2020.

65. Campins L, Boixeda R, Perez-Cordon L, Aranega R, Lopera C, Force L. Early tocilizumab treatment could improve survival among COVID-19 patients. Clinical and experimental rheumatology. 2020;38(3):578.

66. Galván-Román JM, Rodríguez-García SC, Roy-Vallejo E, Marcos-Jiménez A, SánchezAlonso $S$, Fernández-Díaz C, et al. IL-6 serum levels predict severity and response to Tocilizumab in COVID-19: an observational study. J Allergy Clin Immunol. 2020.

67. Rossi B, Nguyen LS, Zimmermann P, Boucenna F, Dubret L, Baucher L, et al. Effect of Tocilizumab in Hospitalized Patients with Severe COVID-19 Pneumonia: A Case-Control Cohort Study. Pharmaceuticals. 2020;13(10):17.

68. Carvalho V, Turon R, Goncalves B, Ceotto V, Kurtz P, Righy C. Effects of Tocilizumab in Critically III Patients With COVID-19: A Quasi-Experimental Study. medRxiv.

2020:2020.07.13.20149328.

69. Moreno Garcia E, Rico Caballero V, Albiach L, Aguero D, Ambrosioni J, Bodro M, et al. Tocilizumab is associated with reduction of the risk of ICU admission and mortality in patients with SARS-CoV-2 infection. medRxiv. 2020:2020.06.05.20113738.

70. Rossotti R, Travi G, Ughi N, Corradin M, Baiguera C, Fumagalli R, et al. Safety and efficacy of anti-il6-receptor tocilizumab use in severe and critical patients affected by coronavirus disease 2019: A comparative analysis. Journal of Infection. 2020;08:08.

71. Dastan F, Saffaei A, Haseli S, Marjani M, Moniri A, Abtahian Z, et al. Promising effects of tocilizumab in COVID-19: A non-controlled, prospective clinical trial. International Immunopharmacology. 2020;88 (no pagination).

72. Gokhale Y, Mehta R, Karnik N, Kulkarni U, Gokhale S. Tocilizumab improves survival in patients with persistent hypoxia in severe COVID-19 pneumonia. EClinicalMedicine. 2020;24 (no pagination).

73. Ruiz-Antorán B, Sancho-López A, Torres F, Moreno-Torres V, de Pablo-López I, García-López P, et al. Combination of Tocilizumab and Steroids to Improve Mortality in Patients with Severe COVID-19 Infection: A Spanish, Multicenter, Cohort Study. Infectious Diseases and Therapy. 2020. 
74. Guaraldi G, Meschiari M, Cozzi-Lepri A, Milic J, Tonelli R, Menozzi M, et al. Tocilizumab in patients with severe COVID-19: a retrospective cohort study. The Lancet Rheumatology. 2020;2(8):e474-e84.

75. Somers EC, Eschenauer GA, Troost JP, Golob JL, Gandhi TN, Wang L, et al. Tocilizumab for treatment of mechanically ventilated patients with COVID-19. Clinical infectious diseases : an official publication of the Infectious Diseases Society of America. 2020;11.

76. Guisado-Vasco P, Valderas-Ortega S, Carralón-González MM, Roda-Santacruz A, González-Cortijo L, Sotres-Fernández G, et al. Clinical characteristics and outcomes among hospitalized adults with severe COVID-19 admitted to a tertiary medical center and receiving antiviral, antimalarials, glucocorticoids, or immunomodulation with tocilizumab or cyclosporine: A retrospective observational study (COQUIMA cohort). EClinicalMedicine. 77. Tian J, Zhang $M$, Jin $M$, Zhang F, Chu Q, Wang X, et al. Repurposed Tocilizumab in Patients with Severe COVID-19. Journal of immunology. 1950(pagination).

78. Malekzadeh R, Abedini A, Mohsenpour B, Sharifipour E, Ghasemian R, Javad-Mousavi $\mathrm{SA}$, et al. Subcutaneous tocilizumab in adults with severe and critical COVID-19: A prospective open-label uncontrolled multicenter trial. International Immunopharmacology. 2020;89:107102.

79. Gupta S, Wang W, Hayek SS, Chan L, Mathews KS, Melamed ML, et al. Association Between Early Treatment With Tocilizumab and Mortality Among Critically III Patients With COVID-19. JAMA Internal Medicine. 2020.

80. Tsai A, Diawara O, Nahass RG, Brunetti L. Impact of tocilizumab administration on mortality in severe COVID-19. Scientific Reports. 2020;10(1):19131.

81. Mikulska M, Nicolini LA, Signori A, Di Biagio A, Sepulcri C, Russo C, et al. Tocilizumab and steroid treatment in patients with COVID-19 pneumonia. PLoS ONE [Electronic Resource]. 2020;15(8):e0237831.

82. Hill JA, Menon MP, Dhanireddy S, Wurfel MM, Green M, Jain R, et al. Tocilizumab in hospitalized patients with COVID-19: Clinical outcomes, inflammatory marker kinetics, and safety. Journal of Medical Virology.n/a(n/a).

83. Wadud N, Ahmed N, Mannu Shergil M, Khan M, Krishna MG, Gilani A, et al. Improved survival outcome in SARs-CoV-2 (COVID-19) Acute Respiratory Distress Syndrome patients with Tocilizumab administration. medRxiv. 2020:2020.05.13.20100081.

84. Morena V, Milazzo L, Oreni L, Bestetti G, Fossali T, Bassoli C, et al. Off-label use of tocilizumab for the treatment of SARS-CoV-2 pneumonia in Milan, Italy. European Journal of Internal Medicine. 2020;76:36-42.

85. Holt GE, Batra M, Murthi M, Kambali S, Santos K, Bastidas MVP, et al. Lack of tocilizumab effect on mortality in COVID19 patients. Scientific Reports. 2020;10(1):17100.

86. Zheng K-L, Xu Y, Guo Y-F, Diao L, Kong X-Y, Wan X-J, et al. Efficacy and safety of tocilizumab in COVID-19 patients. Aging. 2020;12(19):18878-88.

87. Perrone F, Piccirillo MC, Ascierto PA, Salvarani C, Parrella R, Marata AM, et al. Tocilizumab for patients with COVID-19 pneumonia. The single-arm TOCIVID-19 prospective trial. Journal of Translational Medicine. 2020;18(1):405.

88. Ip A, Berry DA, Hansen E, Goy AH, Pecora AL, Sinclaire BA, et al. Hydroxychloroquine and tocilizumab therapy in COVID-19 patients-An observational study. PloS one. 2020;15(8 August).

89. Rosas I, Bräu N, Waters M, Go RC, Hunter BD, Bhagani S, et al. Tocilizumab in Hospitalized Patients With COVID-19 Pneumonia. medRxiv. 2020:2020.08.27.20183442. 
medRxiv preprint doi: https://doi.org/10.1101/2020.04.23.20076612; this version posted January 18, 2021. The copyright holder for this preprint (which was not certified by peer review) is the author/funder, who has granted medRxiv a license to display the preprint in perpetuity.

It is made available under a CC-BY 4.0 International license.

90. Kewan T, Covut F, Al-Jaghbeer MJ, Rose L, Gopalakrishna KV, Akbik B. Tocilizumab for treatment of patients with severe COVID-19: A retrospective cohort study. EClinicalMedicine. 2020;24 (no pagination). 

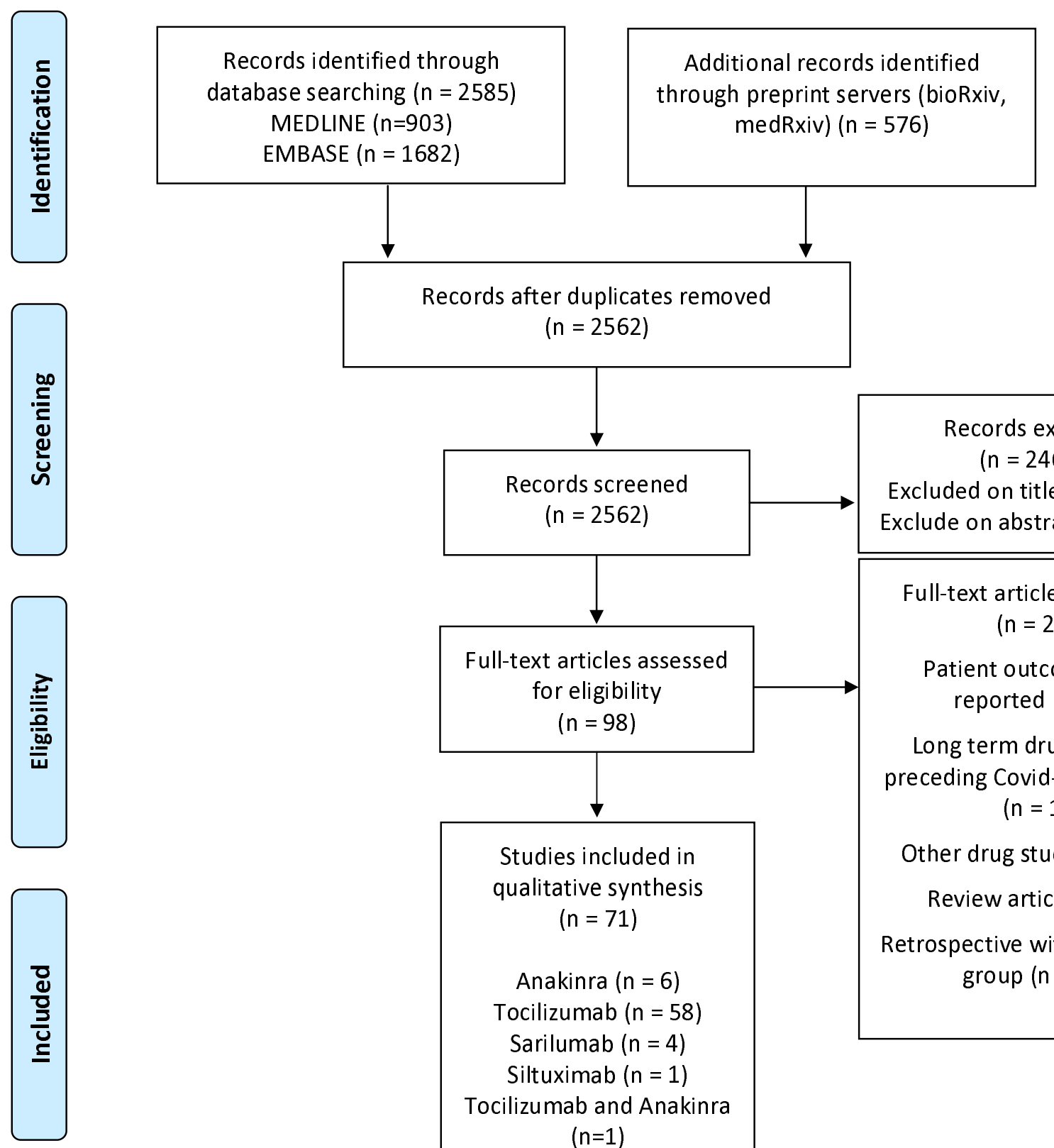

Records after duplicates removed

$(n=2562)$

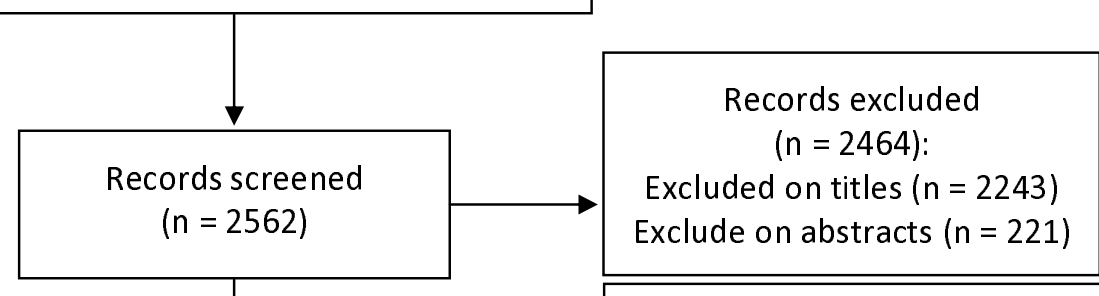

\begin{tabular}{|c|c|}
\hline$\downarrow$ & $\begin{array}{l}\text { Full-text articles excluded } \\
\qquad(\mathrm{n}=27)\end{array}$ \\
\hline $\begin{array}{l}\text { Full-text articles assessed } \\
\text { for eligibility } \\
\qquad(n=98)\end{array}$ & $\begin{array}{l}\text { Patient outcomes not } \\
\text { reported }(n=2)\end{array}$ \\
\hline$\nabla$ & $\begin{array}{l}\text { preceding Covid-19 diagnosis } \\
\qquad(\mathrm{n}=1)\end{array}$ \\
\hline \multirow{2}{*}{$\begin{array}{l}\text { Studies included in } \\
\text { qualitative synthesis } \\
\qquad(n=71)\end{array}$} & Other drug studied $(n=2)$ \\
\hline & Review article $(n=2)$ \\
\hline $\begin{array}{l}\text { Anakinra }(n=6) \\
\text { Tocilizumab }(n=58) \\
\text { Sarilumah }(n=4)\end{array}$ & $\begin{array}{l}\text { Retrospective without control } \\
\text { group }(n=20)\end{array}$ \\
\hline
\end{tabular}

Siltuximab $(n=1)$

Tocilizumab and Anakinra

$$
(n=1)
$$

Tocilizumab and

Sarilumab ( $n=1$ )

Studies included in quantitative synthesis ( $n=57$ )

Clinical trial registries

$$
\text { ( } n=62)
$$


medRxiv preprint doi: https://doi.org/10.1101/2020.04.23.20076612; this version posted January 18, 2021. The copyright holder for this preprint (which was not certified by peer review) is the author/funder, who has granted medRxiv a license to display the preprint in perpetuity. It is made available under a CC-BY 4.0 International license.

Figure 1 - Flow diagram illustrates systematic search and screening strategy, including numbers meeting eligibility criteria and numbers excluded. Last search carried out on $7^{\text {th }}$ January 2021 


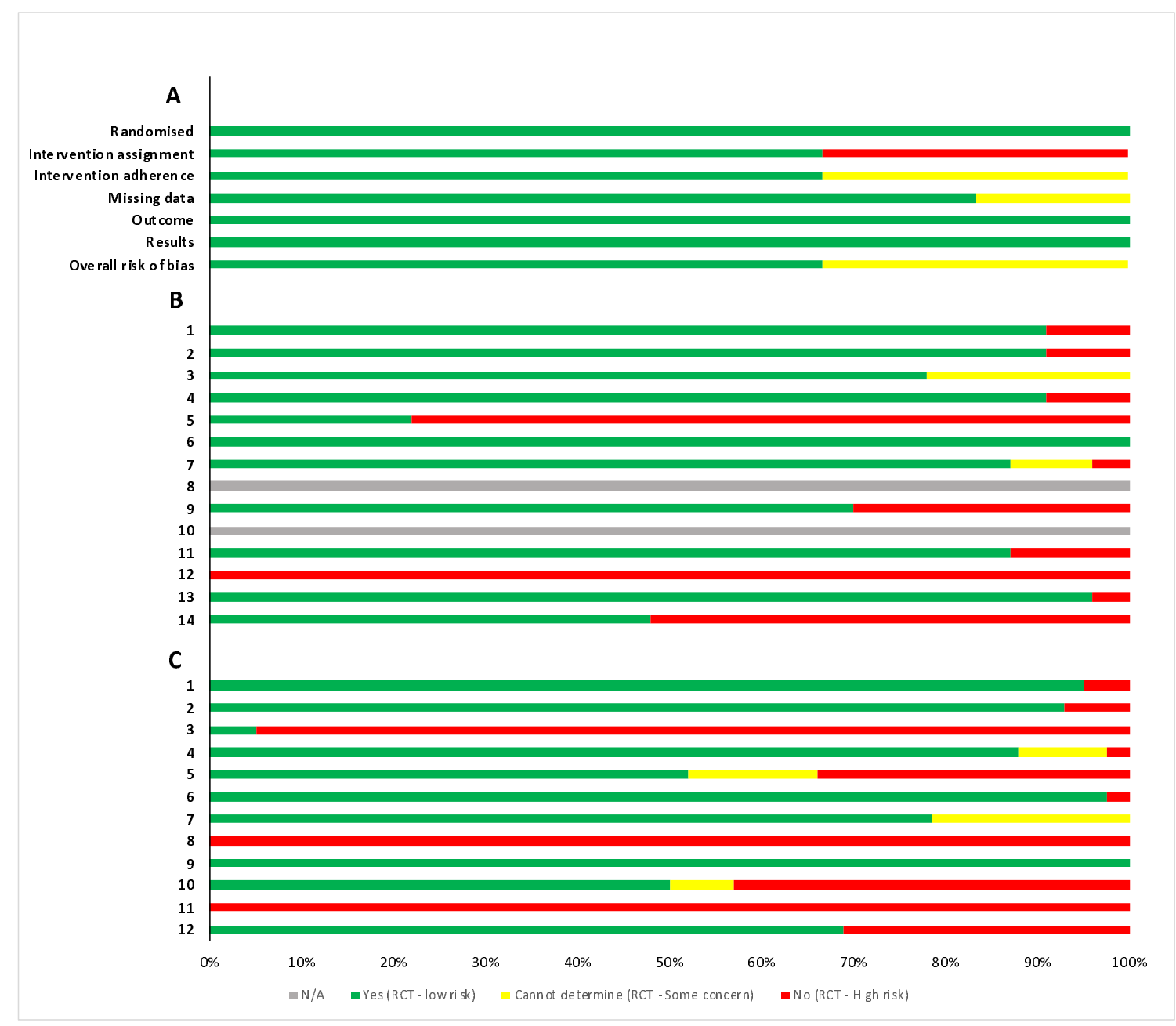

Figure 2-Summary of risk of bias assessment

A - Randomised clinical trials assessed using Cochrane risk of bias 2 tool $(n=6)$. Risk of bias was assessed in six categories and scored as either low risk of bias, some concern, or high risk of bias, before an overall risk of bias was given to each study.

B - Non-randomised prospective studies $(n=23)$. Questions numbered in the first column. 1 . Was the research question or objective in this paper clearly stated? 2 . Was the study population clearly specified and defined? 3. Was the participation rate of eligible persons at least $50 \%$ ? 4 . Were all the subjects selected or recruited from the same or similar populations (including the same time period)? Were inclusion and exclusion criteria for being in the study prespecified and applied uniformly to all participants? 5. Was a sample size justification, power description, or variance and effect estimates provided? 6. For the analyses in this paper, were the exposure(s) of interest measured prior to the outcome(s) being measured? 7 . Was the timeframe sufficient so that one could reasonably expect to see an association between exposure and outcome if it existed? 8. For exposures that can vary in amount or level, did the study examine different levels of the exposure as related to the outcome (e.g., categories of exposure, or exposure measured as continuous variable)? 9. Were the exposure measures (independent variables) clearly defined, valid, reliable, and implemented consistently across all study participants? 10. Was the exposure(s) assessed more than once over time? 11. Were the outcome measures (dependent variables) clearly defined, valid, reliable, and implemented consistently across all study participants? 12. Were the outcome assessors blinded to the exposure status of participants? 13 . Was loss to follow-up 
medRxiv preprint doi: https://doi.org/10.1101/2020.04.23.20076612; this version posted January 18, 2021. The copyright holder for this preprint (which was not certified by peer review) is the author/funder, who has granted medRxiv a license to display the preprint in perpetuity.

It is made available under a CC-BY 4.0 International license.

after baseline $20 \%$ or less? 14 . Were key potential confounding variables measured and adjusted statistically for their impact on the relationship between exposure(s) and outcome(s)?

C - Summary of risk of bias assessment for retrospective studies $(n=42)$. Questions numbered in first column. 1. Was the research question or objective in this paper clearly stated and appropriate? 2. Was the study population clearly specified and defined? 3. Did the authors include a sample size justification? 4. Were controls selected or recruited from the same or similar population that gave rise to the cases (including the same timeframe)? 5. Were the definitions, inclusion and exclusion criteria, algorithms or processes used to identify or select cases and controls valid, reliable, and implemented consistently across all study participants? 6 . Were the cases clearly defined and differentiated from controls? 7. If less than 100 percent of eligible cases and/or controls were selected for the study, were the cases and/or controls randomly selected from those eligible? 8 . Was there use of concurrent controls? 9. Were the investigators able to confirm that the exposure/risk occurred prior to the development of the condition or event that defined a participant as a case? 10. Were the measures of exposure/risk clearly defined, valid, reliable, and implemented consistently (including the same time period) across all study participants? 11. Were the assessors of exposure/risk blinded to the case or control status of participants? 12. Were key potential confounding variables measured and adjusted statistically in the analyses? If matching was used, did the investigators account for matching during study analysis? 


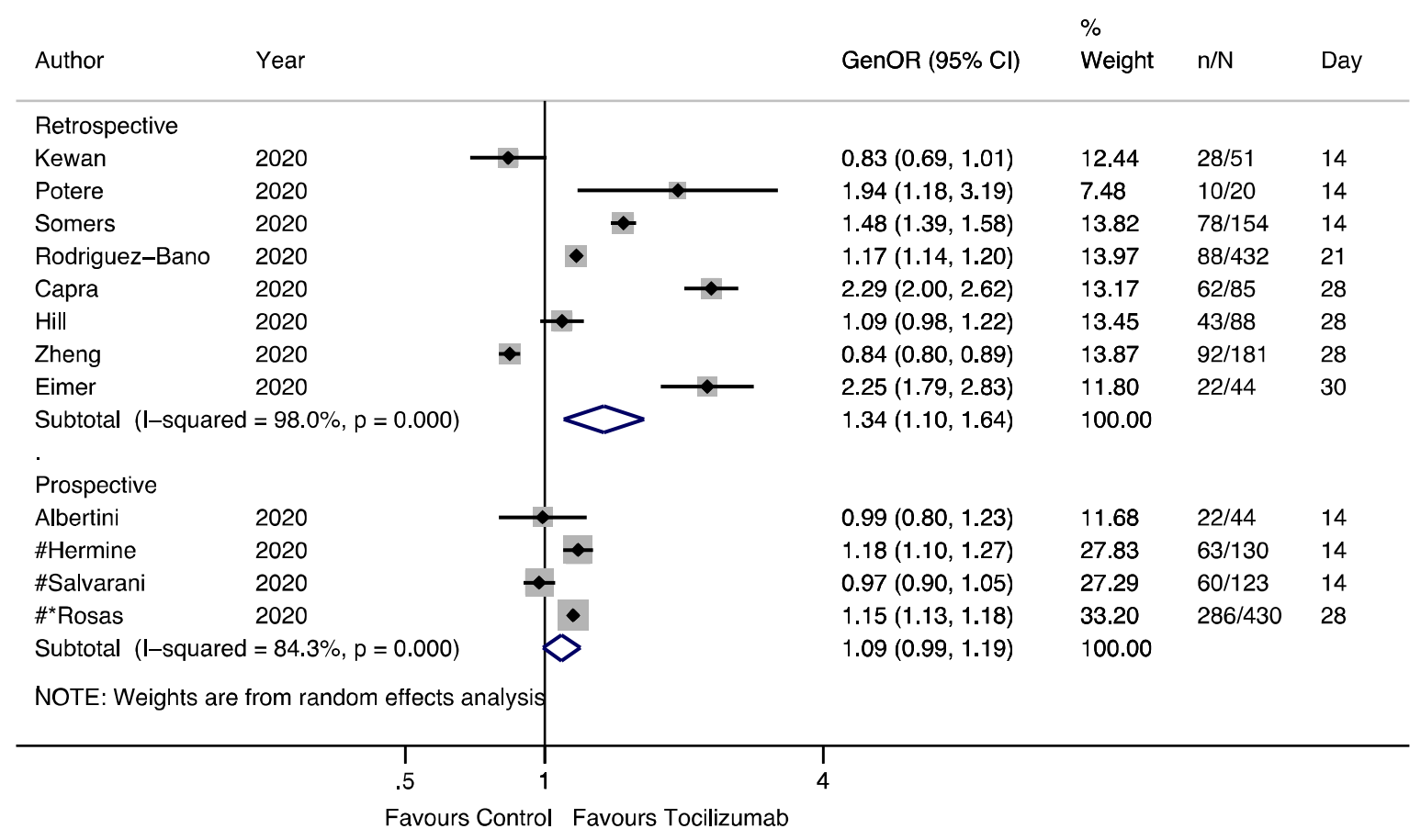

Figure 3 - Tocilizumab generalised odds ratios (OR) for ordinal outcome forest plot. Generalised OR shown for each study with $95 \%$ confidence interval and day at which ordinal outcome recorded. Sample sizes given for patients receiving intervention ( $n$ ) alongside total included $(\mathrm{N})$ in study. Summary estimates presented separately for prospective and retrospective studies.

* non peer-reviewed preprint studies

\# randomised controlled trials 
medRxiv preprint doi: https://doi.org/10.1101/2020.04.23.20076612; this version posted January 18, 2021. The copyright holder for this preprint (which was not certified by peer review) is the author/funder, who has granted medRxiv a license to display the preprint in perpetuity.

\section{It is made available under a CC-BY 4.0 International license .}

A

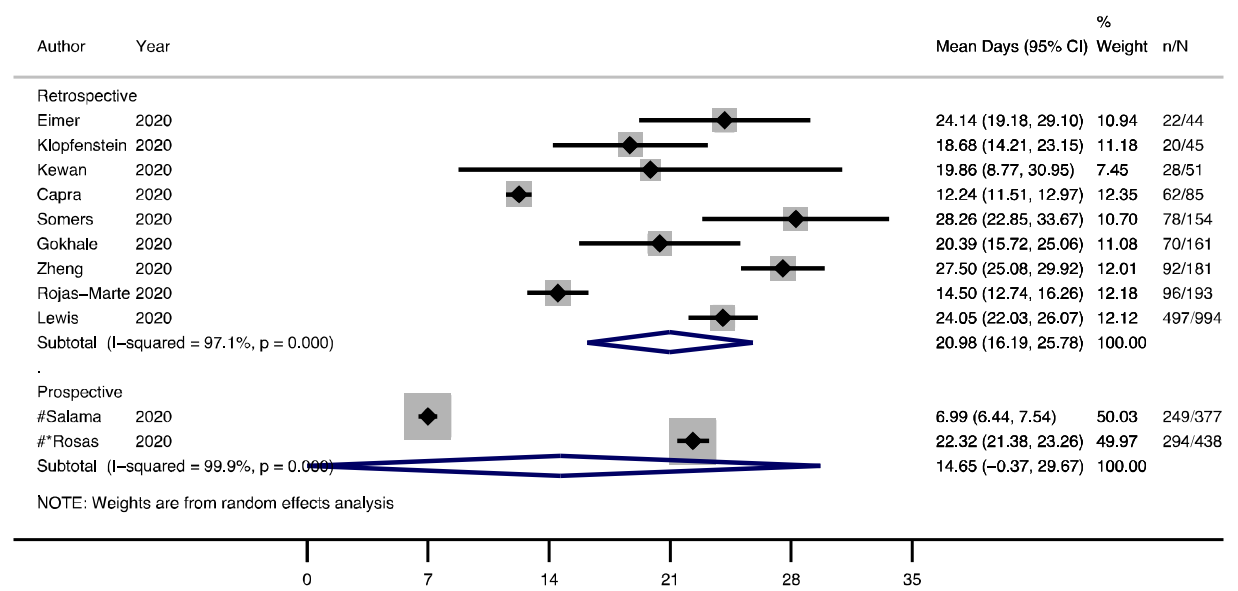

$\mathrm{B}$

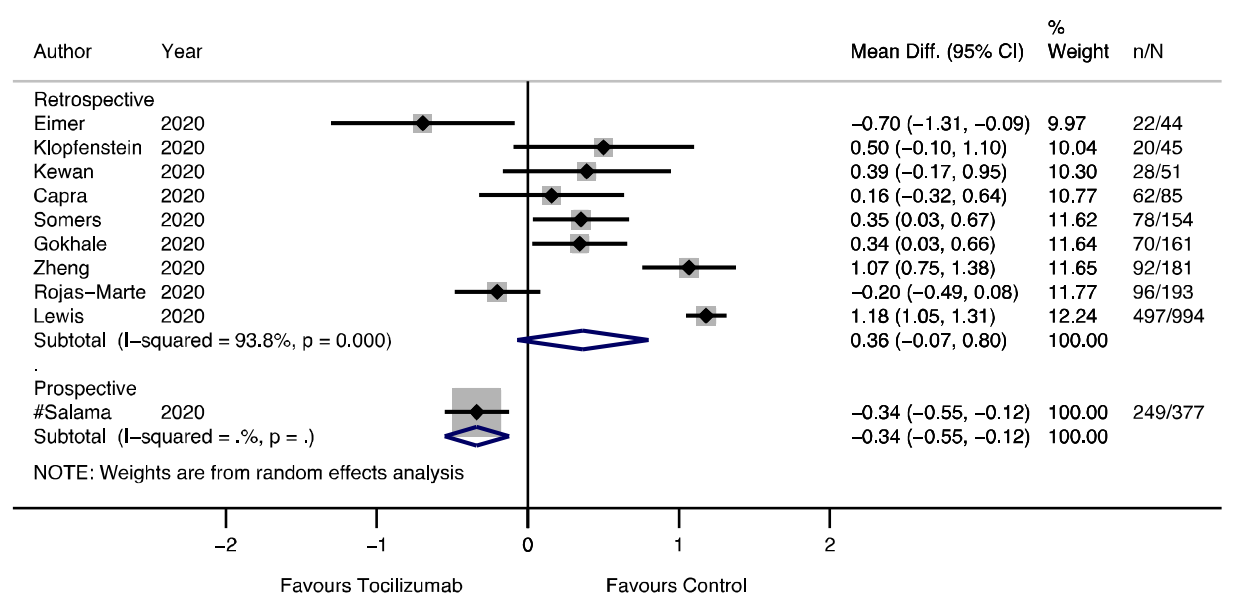

Figure 4 - Tocilizumab duration of hospitalisation (days) forest plot. A: Mean duration of hospital stay. B: Mean difference compared with controls in duration of hospital stay. Effect sizes and associated $95 \%$ confidence intervals presented for each study. Sample sizes given for patients receiving intervention $(n)$ and total included in study (N). Summary estimates presented separately for prospective and retrospective studies. 


\begin{tabular}{|c|c|c|c|c|c|c|}
\hline Author & Year & Drug & aHR $(95 \% \mathrm{Cl})$ & $\begin{array}{l}\% \\
\text { Weight }\end{array}$ & $\mathrm{n} / \mathrm{N}$ & Day \\
\hline \multicolumn{7}{|l|}{ Retrospective } \\
\hline Martinez-Sanz & 2020 & $\mathrm{~T}$ & $0.77(0.48,1.25)$ & 6.53 & $260 / 1229$ & 6 \\
\hline `Ramaswamy & 2020 & $\mathrm{~T}$ & $0.25(0.07,0.90)$ & 2.41 & $21 / 86$ & 7 \\
\hline Ruiz-Antoran & 2020 & $\mathrm{~T}$ & $0.74(0.62,0.89)$ & 8.60 & $238 / 506$ & 12 \\
\hline Guaraldi & 2020 & $\mathrm{~T}$ & $0.38(0.17,0.83)$ & 4.39 & $179 / 544$ & 14 \\
\hline Rodriguez-Bano & 2020 & $\mathrm{~T}$ & $0.12(0.02,0.56)$ & 1.59 & $88 / 432$ & 21 \\
\hline Biran & 2020 & $\mathrm{~T}$ & $0.64(0.47,0.87)$ & 7.82 & $210 / 630$ & 22 \\
\hline Gupta & 2020 & $\mathrm{~T}$ & $0.71(0.56,0.92)$ & 8.22 & $433 / 3925$ & 27 \\
\hline Somers & 2020 & $\rightarrow$ & $0.55(0.33,0.90)$ & 6.36 & $78 / 154$ & 28 \\
\hline Rossi & 2020 & $\mathrm{~T}$ & $0.42(0.22,0.82)$ & 5.23 & $84 / 168$ & 28 \\
\hline Hill & 2020 & $\mathrm{~T}$ & $0.57(0.21,1.52)$ & 3.41 & $43 / 88$ & 28 \\
\hline Ip & 2020 & $\mathrm{~T}$ & $0.76(0.57,1.00)$ & 8.00 & $134 / 547$ & 30 \\
\hline De Rossi & 2020 & $\longrightarrow$ & $0.06(0.02,0.19)$ & 2.88 & $90 / 158$ & 30 \\
\hline Canziani & 2020 & $\mathrm{~T}$ & $0.82(0.42,1.58)$ & 5.20 & $64 / 128$ & 30 \\
\hline Eimer & 2020 & $\mathrm{~T}$ & $0.52(0.19,1.39)$ & 3.38 & $22 / 44$ & 30 \\
\hline Gokhale & 2020 & $\mathrm{~T}$ & $0.62(0.38,0.99)$ & 6.53 & $70 / 161$ & 31 \\
\hline Lewis & 2020 & 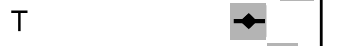 & $0.24(0.18,0.33)$ & 7.85 & $497 / 994$ & NR \\
\hline Tian & 2020 & $\rightarrow$ & $0.47(0.25,0.90)$ & 5.35 & $65 / 195$ & NR \\
\hline Narain & 2020 & $\mathrm{~T}$ & $0.79(0.47,1.32)$ & 6.25 & $73 / 3149$ & NR \\
\hline \multicolumn{7}{|l|}{ Prospective } \\
\hline \#Stone & 2020 & $\mathrm{~T}$ & $1.52(0.41,5.61)$ & 12.27 & $161 / 243$ & 28 \\
\hline Roumier & 2020 & $\mathrm{~T}$ & $0.68(0.31,1.75)$ & 28.04 & $49 / 96$ & 28 \\
\hline \#Hermine & 2020 & $\mathrm{~T}$ & $0.92(0.33,2.53)$ & 20.25 & $63 / 130$ & 28 \\
\hline Mikulska & 2020 & $\mathrm{~T}$ & $0.48(0.23,0.99)$ & 39.43 & $29 / 95$ & 30 \\
\hline \multicolumn{3}{|c|}{ Subtotal $(\mid-$ squared $=0.0 \%, p=0.448)$} & $0.70(0.44,1.10)$ & 100.00 & & \\
\hline \multicolumn{7}{|c|}{ NOTE: Weights are from random effects analysis } \\
\hline & & .01 & & & & \\
\hline
\end{tabular}

Figure 5 - Tocilizumab adjusted hazard ratios (HR) for overall mortality forest plot. Adjusted HRs with associated $95 \%$ confidence interval and day of censorship presented for each study. Sample sizes given for patients receiving intervention $(n)$ and total included $(N)$ in study. Summary estimates presented separately for prospective and retrospective studies.

* non peer-reviewed preprint studies

\# randomised controlled trials

NR, not reported 
medRxiv preprint doi: https://doi.org/10.1101/2020.04.23.20076612; this version posted January 18, 2021. The copyright holder for this preprint (which was not certified by peer review) is the author/funder, who has granted medRxiv a license to display the preprint in perpetuity.

It is made available under a CC-BY 4.0 International license.

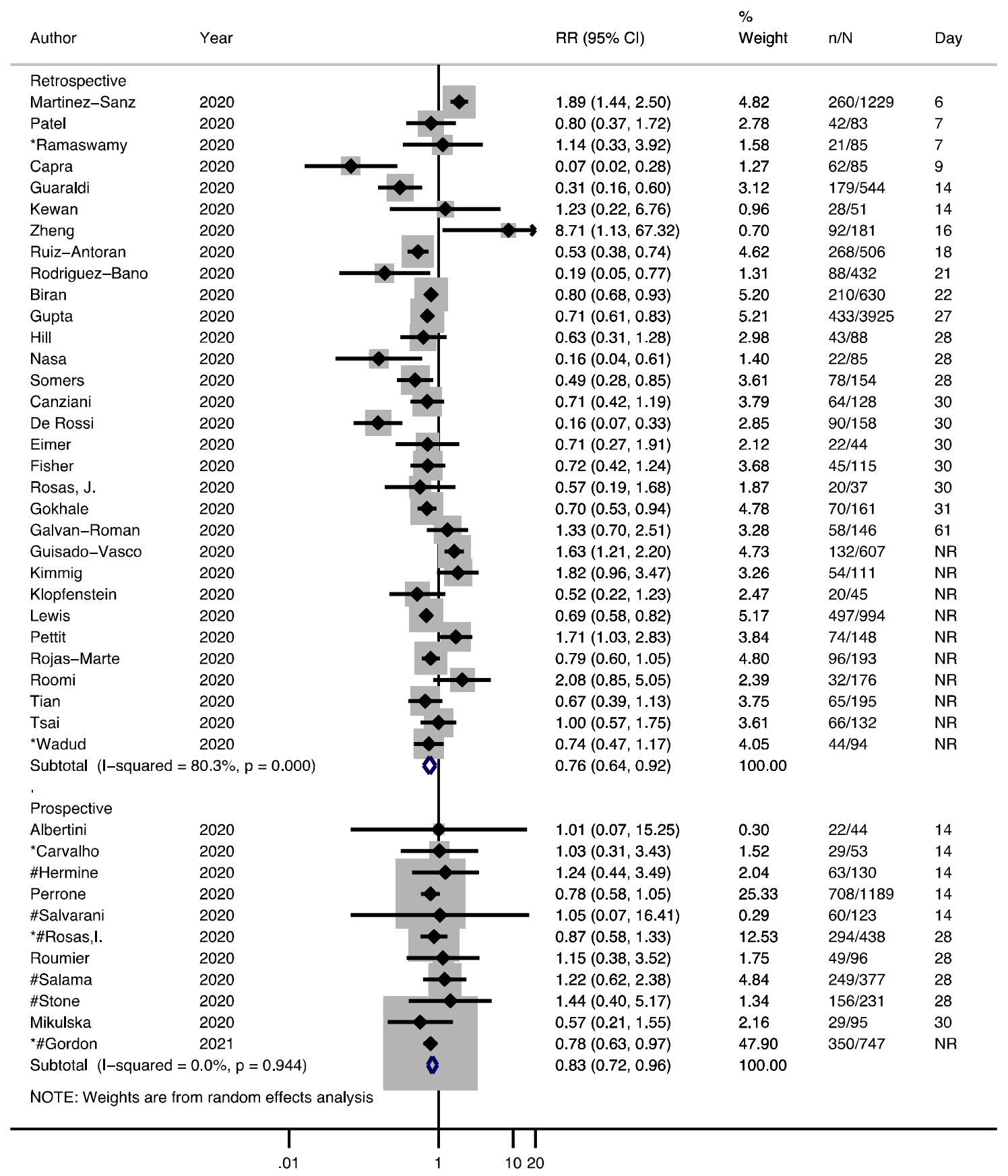

Figure 6 - Tocilizumab mortality risk ratios (RR) forest plot. Risk ratios with associated $95 \%$ confidence interval and day of censorship presented for each study. Sample sizes given for patients receiving intervention $(\mathrm{n})$ and total included in study (N). Summary estimates presented separately for prospective and retrospective studies.

* non peer-reviewed preprint studies

\# randomised controlled trials

NR, not reported 
medRxiv preprint doi: https://doi.org/10.1101/2020.04.23.20076612; this version posted January 18, 2021. The copyright holder for this preprint (which was not certified by peer review) is the author/funder, who has granted medRxiv a license to display the preprint in perpetuity.

It is made available under a CC-BY 4.0 International license. 


\begin{tabular}{|c|c|c|c|c|c|c|c|c|c|c|c|c|c|c|c|c|c|}
\hline Author, year & Drug & $\begin{array}{l}\mathrm{N}, \mathrm{Tx} / \\
\text { Control }\end{array}$ & $\begin{array}{l}\text { Study } \\
\text { country }\end{array}$ & Centre & Study design & $\begin{array}{l}\text { Author, } \\
\text { year }\end{array}$ & Drug & $\begin{array}{l}\mathrm{N}, \mathrm{Tx} / \\
\text { Control }\end{array}$ & $\begin{array}{l}\text { Study } \\
\text { country }\end{array}$ & Centre & Study design & $\begin{array}{l}\text { Author, } \\
\text { year }\end{array}$ & Drug & $\begin{array}{c}\mathrm{N}, \mathrm{Tx} / \\
\text { Control }\end{array}$ & $\begin{array}{l}\text { Study } \\
\text { country }\end{array}$ & Centre & Study design \\
\hline $\begin{array}{l}\text { Balkhair, } \\
2020(26)\end{array}$ & A & $45 / 24$ & Oman & $\begin{array}{l}\text { single } \\
\text { centre }\end{array}$ & $\begin{array}{l}\text { Prospective } \\
\text { with control }\end{array}$ & $\begin{array}{l}\text { Roumier, } \\
2020(32)\end{array}$ & $\mathrm{T}$ & $49 / 47$ & France & $\begin{array}{l}\text { single } \\
\text { centre }\end{array}$ & $\begin{array}{l}\text { Prospective } \\
\text { with control }\end{array}$ & $\begin{array}{l}\text { Kimmig, } \\
2020(33)\end{array}$ & $\mathrm{T}$ & $54 / 57$ & USA & $\begin{array}{l}\text { single } \\
\text { centre }\end{array}$ & Retrospective \\
\hline $\begin{array}{l}\text { Huet, } \\
2020(29)\end{array}$ & A & $52 / 44$ & France & $\begin{array}{l}\text { single } \\
\text { centre }\end{array}$ & $\begin{array}{l}\text { Prospective } \\
\text { with control }\end{array}$ & $\begin{array}{l}\text { Salama, } \\
\text { 2020(22) }\end{array}$ & $\mathrm{T}$ & $\begin{array}{c}249 / \\
128\end{array}$ & USA & $\begin{array}{l}\text { multi- } \\
\text { centre }\end{array}$ & $\begin{array}{l}\text { Double blind } \\
\text { RCT }\end{array}$ & $\begin{array}{c}\text { Klopfenste } \\
\text { in, } \\
2020(34) \\
\end{array}$ & $\mathrm{T}$ & $20 / 25$ & France & $\begin{array}{l}\text { single } \\
\text { centre }\end{array}$ & Retrospective \\
\hline $\begin{array}{l}\text { Kooistra, } \\
2020(35)\end{array}$ & A & $21 / 39$ & $\begin{array}{l}\text { Netherla } \\
\text { nds }\end{array}$ & $\begin{array}{l}\text { multi- } \\
\text { centre }\end{array}$ & $\begin{array}{l}\text { Prospective } \\
\text { with control }\end{array}$ & $\begin{array}{l}\text { Salvarani, } \\
2020(36)\end{array}$ & $\mathrm{T}$ & $60 / 63$ & Italy & $\begin{array}{l}\text { multi- } \\
\text { centre }\end{array}$ & Open label RCT & $\begin{array}{l}\text { Lewis, } \\
2020(37)\end{array}$ & $\mathrm{T}$ & $497 / 497$ & USA & $\begin{array}{l}\text { multi- } \\
\text { centre }\end{array}$ & Retrospective \\
\hline $\begin{array}{l}\text { *Kyriazopoul } \\
\text { ou, 2020(28) }\end{array}$ & A & $130 / 130$ & Greece & $\begin{array}{l}\text { multi- } \\
\text { centre }\end{array}$ & Prospective & $\begin{array}{l}\text { *Sanchez- } \\
\text { Montalva, } \\
\text { 2020(38) }\end{array}$ & $T$ & $82 / 0$ & Spain & $\begin{array}{l}\text { single } \\
\text { centre }\end{array}$ & Prospective & $\begin{array}{l}\text { Martinez- } \\
\text { Sanz, } \\
\text { 2020(39) }\end{array}$ & $\mathrm{T}$ & $260 / 969$ & Spain & $\begin{array}{l}\text { multi- } \\
\text { centre }\end{array}$ & Retrospecti陼 \\
\hline $\begin{array}{l}\text { Cauchois, } \\
2020(24)\end{array}$ & A & $12 / 10$ & France & $\begin{array}{l}\text { multi- } \\
\text { centre }\end{array}$ & Retrospective & $\begin{array}{l}\text { Sciascia, } \\
\text { 2020(40) }\end{array}$ & $\mathrm{T}$ & $63 / 0$ & Italy & $\begin{array}{l}\text { multi- } \\
\text { centre }\end{array}$ & Prospective & $\begin{array}{l}\text { Narain, } \\
2020(27)\end{array}$ & $\mathrm{T}$ & $73 / 3076$ & USA & $\begin{array}{l}\text { multi- } \\
\text { centre }\end{array}$ & 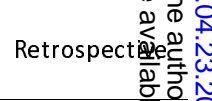 \\
\hline $\begin{array}{l}\text { Cavalli, } \\
2020(25)\end{array}$ & A & $29 / 16$ & Italy & $\begin{array}{l}\text { single } \\
\text { centre }\end{array}$ & Retrospective & $\begin{array}{l}\text { Stone, } \\
2020(21)\end{array}$ & $\mathrm{T}$ & $\begin{array}{c}161 / \\
82\end{array}$ & USA & $\begin{array}{l}\text { multi- } \\
\text { centre }\end{array}$ & $\begin{array}{l}\text { Double blind } \\
\text { RCT }\end{array}$ & $\begin{array}{c}\text { Nasa, } \\
\text { 2020(41) }\end{array}$ & $\mathrm{T}$ & $22 / 63$ & India & $\begin{array}{l}\text { multi- } \\
\text { centre }\end{array}$ & 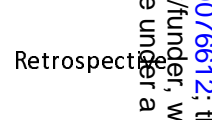 \\
\hline $\begin{array}{l}\text { Narain, } \\
2020(27)\end{array}$ & A & $57 / 3076$ & USA & $\begin{array}{l}\text { multi- } \\
\text { centre }\end{array}$ & Retrospective & $\begin{array}{l}\text { Strohbehn, } \\
2020(42)\end{array}$ & $\mathrm{T}$ & $32 / 41$ & USA & $\begin{array}{l}\text { single } \\
\text { centre }\end{array}$ & $\begin{array}{c}\text { Phase } 2 \\
\text { open label }\end{array}$ & $\begin{array}{c}\text { Patel, } \\
\text { 2020(43) }\end{array}$ & $\mathrm{T}$ & $60 / 1505$ & USA & $\begin{array}{l}\text { single } \\
\text { centre }\end{array}$ & Retrospectives \\
\hline $\begin{array}{l}\text { Benucci, } \\
2020(44)\end{array}$ & Sa & $8 / 0$ & Italy & $\begin{array}{l}\text { single } \\
\text { centre }\end{array}$ & Prospective & $\begin{array}{l}\text { Toniati, } \\
2020(45)\end{array}$ & $\mathrm{T}$ & $100 / 0$ & Italy & $\begin{array}{l}\text { single } \\
\text { centre }\end{array}$ & Prospective & $\begin{array}{l}\text { * Petrak, } \\
2020(46)\end{array}$ & $\mathrm{T}$ & $81 / 37$ & USA & $\begin{array}{l}\text { multi- } \\
\text { centre }\end{array}$ & 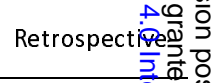 \\
\hline $\begin{array}{l}\text { Della-Torre, } \\
2020(30)\end{array}$ & Sa & $28 / 28$ & Italy & $\begin{array}{l}\text { single } \\
\text { centre }\end{array}$ & $\begin{array}{l}\text { Prospective } \\
\text { with control }\end{array}$ & $\begin{array}{c}\text { Biran, } \\
2020(47)\end{array}$ & $\mathrm{T}$ & $\begin{array}{c}210 / \\
420\end{array}$ & USA & $\begin{array}{l}\text { multi- } \\
\text { centre }\end{array}$ & Retrospective & $\begin{array}{l}\text { Pettit, } \\
\text { 2020(48) }\end{array}$ & $\mathrm{T}$ & $42 / 41$ & USA & $\begin{array}{l}\text { single } \\
\text { centre }\end{array}$ & 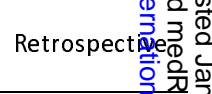 \\
\hline $\begin{array}{l}\text { *Gordon, } \\
2021(20)\end{array}$ & Sa & $45 / 397$ & UK & $\begin{array}{l}\text { multi- } \\
\text { centre }\end{array}$ & Adaptive RCT & $\begin{array}{l}\text { Canziani, } \\
2020(49)\end{array}$ & $\mathrm{T}$ & $64 / 64$ & Italy & $\begin{array}{l}\text { multi- } \\
\text { centre }\end{array}$ & Retrospective & $\begin{array}{l}\text { Potere, } \\
2020(50)\end{array}$ & $\mathrm{T}$ & $74 / 74$ & Italy & $\begin{array}{l}\text { single } \\
\text { centre }\end{array}$ & 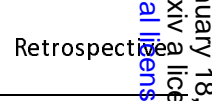 \\
\hline $\begin{array}{l}\text { Gremese, } \\
2020(51)\end{array}$ & Sa & $53 / 0$ & Italy & $\begin{array}{l}\text { single } \\
\text { centre }\end{array}$ & Prospective & $\begin{array}{c}\text { Capra, } 2020 \\
\text { (52) }\end{array}$ & $\mathrm{T}$ & $62 / 23$ & Italy & $\begin{array}{l}\text { single } \\
\text { centre }\end{array}$ & Retrospective & $\begin{array}{c}\text { *Ramaswa } \\
\text { my, } \\
2020(53)\end{array}$ & $\mathrm{T}$ & $10 / 10$ & USA & $\begin{array}{l}\text { multi- } \\
\text { centre }\end{array}$ & Retrospective \\
\hline $\begin{array}{c}\text { Sinha, } \\
2020(54)\end{array}$ & Sa & $255 / 0$ & USA & $\begin{array}{l}\text { single } \\
\text { centre }\end{array}$ & Prospective & $\begin{array}{l}\text { Chillmuri, } \\
2020 \text { (55) }\end{array}$ & $\mathrm{T}$ & $\begin{array}{l}83 / \\
685\end{array}$ & USA & $\begin{array}{l}\text { single } \\
\text { centre }\end{array}$ & Retrospective & $\begin{array}{l}\text { Rodriguez- } \\
\text { Bano, } \\
2020(56)\end{array}$ & $\mathrm{T}$ & $21 / 65$ & Spain & $\begin{array}{l}\text { multi- } \\
\text { centre }\end{array}$ & Retrospective \\
\hline $\begin{array}{c}{ }^{*} \text { Gritti } \\
2020(31)\end{array}$ & $\mathrm{Si}$ & $30 / 30$ & Italy & $\begin{array}{l}\text { single } \\
\text { centre }\end{array}$ & $\begin{array}{l}\text { Prospective } \\
\text { with control }\end{array}$ & $\begin{array}{l}\text { De Rossi, } \\
2020(57)\end{array}$ & $\mathrm{T}$ & $90 / 68$ & Italy & $\begin{array}{l}\text { single } \\
\text { centre }\end{array}$ & Retrospective & $\begin{array}{c}\text { Rojas- } \\
\text { Marte, } \\
\text { 2020(58) }\end{array}$ & $\mathrm{T}$ & $88 / 344$ & USA & $\begin{array}{l}\text { single } \\
\text { centre }\end{array}$ & Retrospective \\
\hline
\end{tabular}




\begin{tabular}{|c|c|c|c|c|c|c|c|c|c|c|c|c|c|c|c|c|c|}
\hline $\begin{array}{l}\text { Albertini, } \\
2020(59)\end{array}$ & $\mathrm{T}$ & $22 / 22$ & France & $\begin{array}{l}\text { single } \\
\text { centre }\end{array}$ & $\begin{array}{l}\text { Prospective } \\
\text { with control }\end{array}$ & $\begin{array}{c}\text { Eimer, } \\
2020(60)\end{array}$ & $\mathrm{T}$ & $22 / 22$ & Sweden & $\begin{array}{l}\text { single } \\
\text { centre }\end{array}$ & Retrospective & $\begin{array}{c}\text { Roomi, } \\
2020(61)\end{array}$ & $\mathrm{T}$ & $96 / 97$ & USA & $\begin{array}{l}\text { single } \\
\text { centre }\end{array}$ & Retrospective \\
\hline $\begin{array}{l}\text { Antony, } \\
2020(62)\end{array}$ & $\mathrm{T}$ & $80 / 0$ & USA & $\begin{array}{l}\text { multi- } \\
\text { centre }\end{array}$ & Prospective & $\begin{array}{c}\text { Fisher, } \\
\text { 2020(63) }\end{array}$ & $\mathrm{T}$ & $45 / 70$ & USA & $\begin{array}{l}\text { single } \\
\text { centre }\end{array}$ & Retrospective & $\begin{array}{l}\text { Rosas, } \\
\text { J.(64) }\end{array}$ & $\mathrm{T}$ & $20 / 17$ & Spain & $\begin{array}{l}\text { single } \\
\text { centre }\end{array}$ & Retrospective \\
\hline $\begin{array}{l}\text { Campins, } \\
2020(65)\end{array}$ & $\mathrm{T}$ & $58 / 0$ & Spain & $\begin{array}{l}\text { single } \\
\text { centre }\end{array}$ & Prospective & $\begin{array}{c}\text { Galvan } \\
\text { Roman, } \\
\text { 2020(66) }\end{array}$ & $\mathrm{T}$ & $58 / 88$ & Spain & $\begin{array}{l}\text { single } \\
\text { centre }\end{array}$ & Retrospective & $\begin{array}{c}\text { Rossi, } \\
2020(67)\end{array}$ & $\mathrm{T}$ & $84 / 84$ & France & $\begin{array}{l}\text { single } \\
\text { centre }\end{array}$ & Retrospective \\
\hline $\begin{array}{l}\text { *Carvalho, } \\
2020(68)\end{array}$ & $\mathrm{T}$ & $29 / 24$ & Brazil & $\begin{array}{l}\text { single } \\
\text { centre }\end{array}$ & $\begin{array}{l}\text { Prospective } \\
\text { with control }\end{array}$ & $\begin{array}{l}\text { *Garcia, } \\
\text { 2020(69) }\end{array}$ & $\mathrm{T}$ & $77 / 94$ & Spain & $\begin{array}{l}\text { single } \\
\text { centre }\end{array}$ & Retrospective & $\begin{array}{l}\text { Rossotti, } \\
2020(70)\end{array}$ & $\mathrm{T}$ & $74 / 148$ & Italy & $\begin{array}{l}\text { single } \\
\text { centre }\end{array}$ & Retrospective \\
\hline $\begin{array}{c}\text { Dastan, } \\
2020(71)\end{array}$ & $\mathrm{T}$ & $42 / 0$ & Iran & $\begin{array}{l}\text { single } \\
\text { centre }\end{array}$ & Prospective & $\begin{array}{l}\text { Gokhale, } \\
2020(72)\end{array}$ & $\mathrm{T}$ & $70 / 91$ & India & $\begin{array}{l}\text { single } \\
\text { centre }\end{array}$ & Retrospective & $\begin{array}{c}\text { Ruiz- } \\
\text { Antoran, } \\
\text { 2020(73) }\end{array}$ & $\mathrm{T}$ & $268 / 238$ & Spain & $\begin{array}{l}\text { multi- } \\
\text { centre }\end{array}$ & 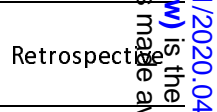 \\
\hline $\begin{array}{l}\text { * Gordon, } \\
\text { 2021(20) }\end{array}$ & $\mathrm{T}$ & $350 / 397$ & UK & $\begin{array}{l}\text { multi- } \\
\text { centre }\end{array}$ & Adaptive RCT & $\begin{array}{l}\text { Guaraldi, } \\
2020(74)\end{array}$ & $\mathrm{T}$ & $\begin{array}{l}179 / \\
365\end{array}$ & Italy & $\begin{array}{l}\text { multi- } \\
\text { centre }\end{array}$ & Retrospective & $\begin{array}{l}\text { Somers, } \\
2020(75)\end{array}$ & $\mathrm{T}$ & $78 / 76$ & USA & $\begin{array}{l}\text { single } \\
\text { centre }\end{array}$ & 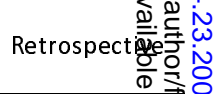 \\
\hline $\begin{array}{l}\text { Hermine, } \\
2020(23)\end{array}$ & $\mathrm{T}$ & $63 / 67$ & France & $\begin{array}{l}\text { multi- } \\
\text { centre }\end{array}$ & $\begin{array}{c}\text { Open-label } \\
\text { RCT }\end{array}$ & $\begin{array}{l}\text { Guisado- } \\
\text { Vasco, } \\
2020(76)\end{array}$ & $\mathrm{T}$ & $\begin{array}{l}132 / \\
475\end{array}$ & Spain & $\begin{array}{l}\text { single } \\
\text { centre }\end{array}$ & Retrospective & $\begin{array}{c}\text { Tian, } \\
\text { 2020(77) }\end{array}$ & $\mathrm{T}$ & $65 / 130$ & China & $\begin{array}{l}\text { multi- } \\
\text { centre }\end{array}$ & 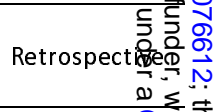 \\
\hline $\begin{array}{c}\text { Malekzadeh, } \\
2020(78)\end{array}$ & $\mathrm{T}$ & $126 / 0$ & Iran & $\begin{array}{l}\text { multi- } \\
\text { centre }\end{array}$ & Prospective & $\begin{array}{c}\text { Gupta, } \\
2020(79)\end{array}$ & $\mathrm{T}$ & $\begin{array}{l}433 / \\
3492\end{array}$ & USA & $\begin{array}{l}\text { multi- } \\
\text { centre }\end{array}$ & Retrospective & $\begin{array}{c}\text { Tsai, } \\
2020(80)\end{array}$ & $\mathrm{T}$ & $66 / 66$ & USA & $\begin{array}{l}\text { single } \\
\text { centre }\end{array}$ & 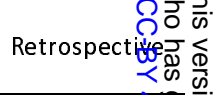 \\
\hline $\begin{array}{l}\text { Mikulska, } \\
2020(81)\end{array}$ & $\mathrm{T}$ & $29 / 66$ & Italy & $\begin{array}{l}\text { single } \\
\text { centre }\end{array}$ & $\begin{array}{l}\text { Prospective } \\
\text { with control }\end{array}$ & $\begin{array}{c}\text { Hill, } \\
\text { 2020(82) }\end{array}$ & $\mathrm{T}$ & $43 / 45$ & USA & $\begin{array}{l}\text { single } \\
\text { centre }\end{array}$ & Retrospective & $\begin{array}{l}\text { * Wadud, } \\
2020(83)\end{array}$ & $\mathrm{T}$ & $84 / 84$ & USA & $\begin{array}{l}\text { single } \\
\text { centre }\end{array}$ & 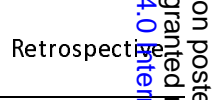 \\
\hline $\begin{array}{l}\text { Morena, } \\
2020(84)\end{array}$ & $\mathrm{T}$ & $51 / 0$ & Italy & $\begin{array}{l}\text { single } \\
\text { centre }\end{array}$ & Prospective & $\begin{array}{c}\text { Holt, } \\
2020(85)\end{array}$ & $\mathrm{T}$ & $24 / 30$ & USA & $\begin{array}{l}\text { single } \\
\text { centre }\end{array}$ & Retrospective & $\begin{array}{l}\text { Zheng, } \\
\text { 2020(86) }\end{array}$ & $\mathrm{T}$ & $92 / 89$ & China & $\begin{array}{l}\text { single } \\
\text { centre }\end{array}$ & 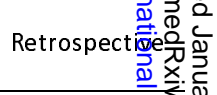 \\
\hline $\begin{array}{c}\text { Perrone } \\
2020(87)\end{array}$ & $\mathrm{T}$ & $708 / 481$ & Italy & $\begin{array}{l}\text { multi- } \\
\text { centre }\end{array}$ & $\begin{array}{c}\text { Single arm } \\
\text { open label \& } \\
\text { Validation } \\
\end{array}$ & Ip, 2020(88) & $\mathrm{T}$ & $134 / 413$ & USA & $\begin{array}{l}\text { multi- } \\
\text { centre }\end{array}$ & Retrospective & & & & & & 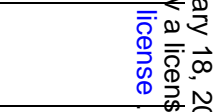 \\
\hline $\begin{array}{c}\text { *Rosas, } \\
2020(89)\end{array}$ & $\mathrm{T}$ & $294 / 144$ & USA & $\begin{array}{l}\text { multi- } \\
\text { centre }\end{array}$ & $\begin{array}{l}\text { Double blind } \\
\text { RCT }\end{array}$ & $\begin{array}{c}\text { Kewan, } \\
2020(90)\end{array}$ & $\mathrm{T}$ & $28 / 23$ & USA & $\begin{array}{l}\text { single } \\
\text { centre }\end{array}$ & Retrospective & & & & & & 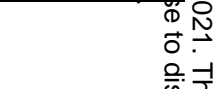 \\
\hline & \multicolumn{17}{|c|}{ 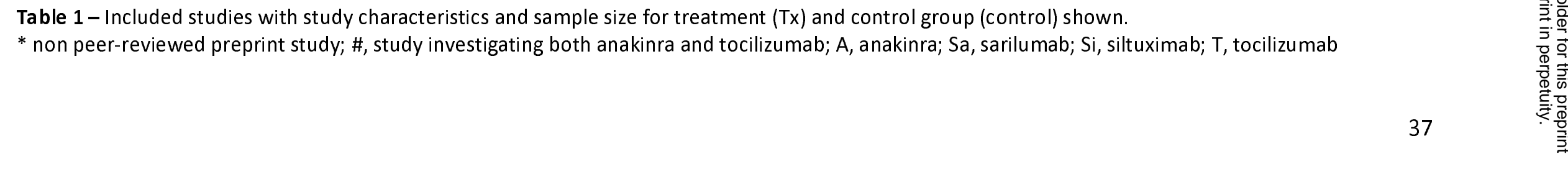 } \\
\hline
\end{tabular}




\begin{tabular}{|c|c|c|}
\hline Author, year & Therapy & Adverse effects \\
\hline Balkhair, 2020 & Anakinra & Treatment: infection (11\%), ALT rise (14\%). Control: infection (18\%), ALT rise (9\%) \\
\hline Huet, 2020 & Anakinra & Treatment: ALT rise (13\%). Control: 9\% in anakinra \\
\hline Kooistra, 2020 & Anakinra & Treatment: secondary infection (33\%). Control: secondary infection (23\%) \\
\hline Cauchois, 2020 & Anakinra & $\mathrm{N} / \mathrm{R}$ \\
\hline Cavalli, 2020 & Anakinra & Treatment: staphylococcus epidermis (14\%); deranged liver enzymes (10\%). Control: bacteraemia (13\%); deranged liver enzymes (31\%). \\
\hline Narain, 2020 & Anakinra & $\mathrm{N} / \mathrm{R}$ \\
\hline Della-Torre, 2020 & Sarilumab & $\begin{array}{l}\text { Treatment: Infections (21\%); neutropenia (14\%); liver enzyme increase (14\%); thromboembolism (7\%). Control: Infections (18\%); thromboembolism } \\
(7 \%)\end{array}$ \\
\hline * Gordon, 2021 & Sarilumab & No serious event in sarilumab group, and 11 events in control \\
\hline Gremese, 2020 & Sarilumab & neutropenia (15\%); elevated liver enzymes (11\%) \\
\hline Sinha, 2020 & $\begin{array}{l}\text { Sarilumab or } \\
\text { Tocilizumab }\end{array}$ & bacterial infection (13\%) \\
\hline * Gritti 2020 & Siltuximab & $\mathrm{Nil}$ \\
\hline Albertini, 2020 & Tocilizumab & elevated liver enzymes (64\%) \\
\hline Antony, 2020 & Tocilizumab & $\mathrm{N} / \mathrm{R}$ \\
\hline Campins, 2020 & Tocilizumab & Nil \\
\hline * Carvalho, 2020 & Tocilizumab & $\mathrm{Nil}$ \\
\hline Chillmuri, 2020 & Tocilizumab & $\mathrm{N} / \mathrm{R}$ \\
\hline Dastan, 2020 & Tocilizumab & transient diplopia (4.8\%); Bell's palsy (2.4\%) \\
\hline * Gordon, 2021 & Tocilizumab & 9 serious adverse events in Tocilizumab group and 11 events in control \\
\hline Hermine, 2020 & Tocilizumab & Treatment: Serious adverse events occurred in 20 (32\%). Control: 29 (43\%) (PQ]=国) \\
\hline Lewis, 2020 & Tocilizumab & Increased infection rate in treatment group (aOR $4.18 ; 95 \% \mathrm{Cl} 2.72-6.52$ ) \\
\hline Malekzadeh, 2020 & Tocilizumab & $\mathrm{Nil}$ \\
\hline Mikulska, 2020 & Tocilizumab & $\mathrm{N} / \mathrm{R}$ \\
\hline Morena, 2020 & Tocilizumab & elevated liver enzymes (29\%), thrombocytopenia (14\%), neutropenia (6\%), infections (24\%) \\
\hline Nasa, 2020 & Tocilizumab & two patients (9.1\%) developed deranged LFTs and two patients (9.1\%) developed secondary sepsis. \\
\hline Perrone, 2020 & Tocilizumab & allergic reactions $(0.4 \%)$, de ranged liver enzymes $(10.5 \%)$ \\
\hline * Petrak, 2020 & Tocilizumab & $\mathrm{N} / \mathrm{R}$ \\
\hline * Rosas,I., 2020 & Tocilizumab & 66 serious infections (21\%) were reported in the treatment arm and $49(25.9 \%)$ in the place bo arm. Adverse events similar in both arms \\
\hline Roumier, 2020 & Tocilizumab & 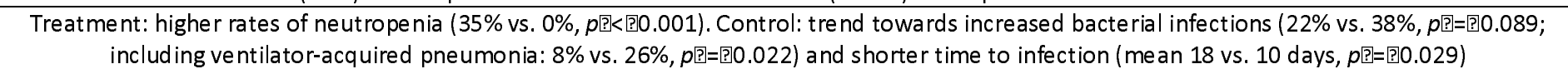 \\
\hline
\end{tabular}


Salama, 2020 Salvarani, 2020

\section{* Sanchez-Montalva, 2020} Sciascia, 2020

Stone, 2020

Strohbehn, 2020

Toniati, 2020

Biran, 2020

Canziani, 2020

Capra, 2020

De Rossi, 2020

Eimer, 2020

Fisher, 2020

Galvan Roman, 2020

* Garcia, 2020

Gokhale, 2020

Guaraldi, 2020

Guisado-Vasco, 2020

Gupta, 2020

Hill, 2020

Holt, 2020

Ip, 2020

Kewan, 2020

Kimmig, 2020

Klopfenstein, 2020

Martinez-Sanz, 2020

Narain, 2020

Patel, 2020

Pettit, 2020

Potere, 2020

* Ramaswamy, 2020

Rodriguez-Bano, 2020

Rojas-Marte, 2020 Roomi, 2020
Tocilizumab Tocilizumab Tocilizumab Tocilizumab

Tocilizumab

Tocilizumab Tocilizumab Tocilizumab Tocilizumab Tocilizumab Tocilizumab Tocilizumab Tocilizumab Tocilizumab Tocilizumab Tocilizumab Tocilizumab Tocilizumab Tocilizumab Tocilizumab Tocilizumab Tocilizumab Tocilizumab Tocilizumab Tocilizumab Tocilizumab Tocil izumab Tocilizumab

Tocilizumab Tocilizumab Tocilizumab Tocilizumab Tocil izumab Tocilizumab
Serious adverse events occurred in 38 of 250 patients (15.2\%) in the tocilizumab group and 25 of 127 patients (19.7\%) in the placebo group

Nil
$\mathrm{Nil}$
$\mathrm{Nil}$

Neutropenia developed in 22 patients in the treatment group, as compared with only 1 patient in the placebo group ( $P=0.002)$, but serious infections occurred in fewer patients in the tocilizumab group (13 [8.1\%] vs. 14 [17.3\%]; $P=0.03$ ).

Treatment: bacterial infections (15.6\%). Control: not reported septic shock (2\%), gastrointestinal perforation (1\%)

Treatment: secondary bacterial infection in $17 \%$. Control: secondary bacterial infection in $13 \%$

HR 0.71 (95\% Cl 0.38-1.32) for infection; HR 0.89 (95\% Cl 0.39-2.06) for thrombosis; HR 1.17 (95\% Cl 0.47-2.92) for bleeding $\mathrm{Nil}$

Significant rise (from $44.3+/-28.3$ to $103+/-141.3$ ) in ALT in patients taking IV dose Blood stream infection: $4(18 \%)$ in treatment group vs. $6(27 \%)$ in contro

No increased risk of secondary infection (OR $1.17 ; 95 \% \mathrm{Cl} 0.51-2.71$ )

\begin{tabular}{c} 
No increased risk of secondary infection (OR $1.17 ; 95 \% \mathrm{Cl} 0.51-2.71)$ \\
$\mathrm{N} / \mathrm{R}$ \\
$\mathrm{N} / \mathrm{R}$ \\
$\mathrm{N} / \mathrm{R}$ \\
\hline $13 \%$ treated diagnosed with new infections vs $4 \%$ in control $(\mathrm{p}<0.0001)$ \\
\hline $\mathrm{N} / \mathrm{R}$
\end{tabular}

$N / R$

Treated and control patients experienced the following adverse events: secondary infection (140 [32.3\%] vs 1085 [31.1\%]); AST or ALT leve elevation of more than $250 \mathrm{U} / \mathrm{L}(72$ [16.6\%] vs 452 [12.9\%])

In treatment vs control group, there was increased sepsis ( $21 \%$ and $16 \%)$, ALT rise ( $9 \%$ vs $4 \%$ ) and thrombocytopenia ( $12 \%$ vs $4 \%$ ) $\mathrm{N} / \mathrm{R}$ $N / R$

Similar rates of hospital-acquired infections occurred in both cohorts ( $18 \%$ in treatment and $22 \%$ in control).

Treatment associated with increased secondary bacterial (aOR $2.76 ; 95 \% \mathrm{Cl} 1.11-7.2)$ and fungal $(5.6 \% \mathrm{vs} .0 \%, \mathrm{p}=0.112)$ infections $\mathrm{N} / \mathrm{R}$ $\mathrm{N} / \mathrm{R}$

$N / R$ $\mathrm{N} / \mathrm{R}$

Overall infection rate was similar $(16.2 \%$ treatment vs. $17.5 \%$ control), but late on-set infections occurred in more treated patients ( $23 \%$ vs $8 \%$; $\mathrm{p}=0.013$ ). In treated, $26 \%$ experienced an increase to $>5$ times upper limit normal of LFTs $\mathrm{Nil}$

secondary bacterial infection similar in both groups (treated $12.5 \%$ vs. $10.3 \%$ control; $p=0.57$ )

Bacteraemia was more common in the control group ( $24 \%$ vs. $13 \%$, Pl=国 0.43 ), while fungemia was similar for both ( $3 \%$ vs. $4 \%$, P国=0.72) $N / R$ 
Rosas, J. 2020

Rossi, 2020

Rossotti, 2020

Ruiz-Antoran, 2020

Somers, 2020

Tian, 2020

Tsai, 2020

* Wadud, 2020

Zheng, 2020
Tocilizumab

Tocilizumab

Tocil izumab

Tocilizumab

Tocilizumab

Tocilizumab

Tocilizumab

Tocilizumab

Tocilizumab
$\mathrm{Nil}$

infectious complication in $32.4 \%$

$32.6 \%$ in treated vs. $30.3 \%$ in control had increase in liver enzymes. Bacteraemia in 1 patient $(0.4 \%)$ higher rate of supe rinfection in treated group (54\% vs $26 \% ; p<0.001$ )

Deranged LFTs in $14 \%$ of tocilizumab and $14 \%$ of control group

Table 2 - Treatment related adverse events. Adverse events for drug under study reported. Adverse events for control population reported where applicable. * non peer-reviewed preprint study 
